Article

\title{
Determinants of Companies that Disclose High-Quality Integrated Reports
}

\author{
Petra F. A. Dilling *(1) and Sinan Caykoylu \\ School of Management, New York Institute of Technology, Vancouver, BC V7Y 1K8, Canada \\ * Correspondence: pdilling@nyit.edu; Tel.: +1-604-639-0942
}

Received: 26 May 2019; Accepted: 2 July 2019; Published: 9 July 2019

check for updates

\begin{abstract}
Integrated reporting is becoming increasingly popular. The focus of this study was to assess the overall integrated reporting quality of global companies and find determinants of high-level integrated reporting. Qualitative text analysis was performed on the 2017 integrated reports of 110 global organizations to determine in what way companies report on specific topics related to the six capitals: social and relationship, human, intellectual, manufacturing, natural, and financial. Using a novel assessment technique, scores were then assigned according to the details provided in the integrated reports on the various topics. This was done for each form of capital, and the total integrated score was subsequently calculated as the average between all the capital scores. Finally, a regression analysis was performed to determine the characteristics of high-quality integrated reporters. The results of univariate analysis and two-stage least squares instrumental variable (2SLS) regression indicate that companies of a larger size with a higher female board ratio and listing in the International Integrated Reporting Committee (IIRC) examples database are more likely to publish a higher quality integrated report. The results imply that these variables are the main disclosure drivers. However, a significant negative correlation was found between integrated report quality and the variables related to female executive ratio, external board member ratio, profitability, leverage, and previous report experience, as well as report length. No significant association was found between the location and industry group and report quality. The empirical evidence of this study shows that even though integrated reporting has become more common overall, the comparability and quality of the reports still remain low.
\end{abstract}

Keywords: integrated reporting; sustainability; content analysis; corporate social responsibility (CSR); long-term value creation; six capitals; legitimacy theory; stakeholder theory; voluntary disclosure theory; qualitative research; empirical research; regression; OLS; 2SLS; endogeneity; instrumental variables

\section{Introduction}

Organizations typically prepare integrated reports to provide report readers with a holistic view of corporate performance and long-term value creation. This is often done for good reason. In fact, there seems to be a tremendous demand for reporting on integrated financial, social, and environmental metrics [1]. Multiple sources state that integrated reporting is "the new reporting", as it combines not only financial as well as non-financial reporting, but also focuses on reporting on long-term value creation [2-5]. Integrated reporting (IR) is considered also as better quality reporting that outlines the connections between the social, environmental, and economic dimensions of a company [6].

Today, most integrated reports are still prepared voluntarily. Nonetheless, integrated reporting has been gaining traction ever since the International Integrated Reporting Committee (IIRC) was established in 2010 [7]. In South Africa, the evolution of integrated reporting started even earlier, and the preparation of an integrated report has been mandatory for companies listed at the Johannesburg 
Stock Exchange (JSE) since 2009. (It has to be noted that the JSE requirement does not specifically ask for integrated reports to be prepared according to the International $<\mathrm{IR}>$ Framework [8].) Since then, companies all over the world have started to embrace integrated reporting; one prominent example would be in Japan, where no formal requirement for an integrated report exists, but more and more companies have started to prepare them over the last few years [9].

The focus of this study is assessing the overall integrated reporting level and finding the determinants for better quality integrated reporting. To accomplish this, a qualitative text analysis of all integrated reports was performed to determine how companies report on specific topics related to the six capitals: social and relationship, human, intellectual, manufacturing, natural, and financial capital. Such disclosure can range from customer satisfaction metrics to stakeholder engagement key performance indicators (KPIs), from energy savings and carbon footprint numbers to dollar figures for investment in innovations, and from return to shareholders to social value input or investment in property, plant, and equipment (PPE). Then, scores are assigned according to the content details provided in the integrated reports on the various topics. This is done for each individual of the six capitals. Finally, a total integrated report quality score is calculated as the average among all the capital scores. This is followed by a correlation analysis of the independent variables and the dependent variable. Lastly, a linear regression analysis is performed to determine the characteristics of companies that proved to be "high quality reporters" of integrated information. The empirical research results make an important contribution to the existing literature by identifying certain corporate characteristics for a set of global companies such as a larger size, a higher female board ratio, or being listed in the Integrated Reporting examples database, which leads to a higher likelihood of publishing a higher quality integrated report. However, a negative significant correlation was found between the determinants related to female executive ratio, profitability and leverage, and integrated report quality. Overall, the results of this study show there are certain characteristics that make it more likely for companies to publish a higher quality integrated report. In addition, although integrated reporting might have become increasingly popular, the comparability and quality of the reports remain at a low level.

The intention of this research study is to not only to determine the status quo of global integrated reporting, but also to provide reporting companies and regulators with insights into current practice and thereby assist with the development of processes, policies, and regulations.

The literature review will represent the second part of this paper followed by the research approach, methodology, and results. The last part of the paper will include the conclusion and recommendations with suggestions for further research.

\section{Theoretical Framework, Literature Review, and Hypotheses Development}

\subsection{Theoretical Framework}

Integrated reporting seeks to concisely communicate a firm's value through a holistic picture that combines financial and non-financial information [2]. As mentioned above, in 2009, the Johannesburg Securities Exchange started requiring listed companies to combine financial performance information with sustainability performance information within their annual reports and issue an integrated report or disclose why they had not done so using the "comply or explain approach" [10]. By doing so, South Africa was the first country that required at least a certain group of companies to prepare an integrated report. Shortly after, when the IIRC was formed in 2010, one of the main objectives was that companies provide a short and concise report outlining an organization's social, environmental, and economic activities, as well as outcomes, risks, and opportunities in an integrated manner, replacing all other reports [11]. This was not easy to implement, as this kind of information disclosure is often regulated by financial accounting regulatory bodies, securities commissions, and others. Accordingly, the objective was somewhat modified in that the newest International Integrated Reporting Framework $<\mathrm{IR}>$ supports the inclusion of financial and other information, and uses principles and concepts with a 
focus on increased cohesion and efficiency regarding the reporting process, while adopting the concept of integrated thinking in order to break down internal silos and reduce duplication [11]. Furthermore, “...value is created through an organization's business model, which takes inputs from the six capitals ... and transfers them through business activities to produce outputs and outcomes that create or destroy value for the organization, its stakeholders, society, and the environment" [11].

Integrated reporting has been praised by many for its perceived superiority over mainstream corporate reporting $[12,13]$. In contrast, current financial reporting has been criticized for not being relevant or timely enough $[13,14]$, and it is often argued that information in traditional financial reports is not useful when trying to assess the long-term viability of an organization [11,15-18].

The level and scope of voluntary information disclosure is an important strategic decision for any company. Prior studies that have examined the relationship between characteristics and organizational report quality have done so by using the concepts of agency, stakeholder, legitimacy, and signaling theory. According to agency theory, it is assumed that companies will disclose more information voluntarily to decrease agency costs, which develop through disagreements between stakeholders and managers [19]. With regard to decision making, disclosed information will be used not only by the leadership team and owners, but also by investors and stakeholders for the purpose of assessing management decisions [20]. Stakeholder theory extended this concept by applying it to other stakeholders [21]. Signaling theory posits that through information disclosure, the company sends a signal to the market to reduce information asymmetry, minimize financing costs, and increase company value [22]. Lastly, legitimacy theory suggests a social contract between the organization and society, and in the case that the information disclosure is not sufficient, voluntary information disclosure is deemed necessary [23]. When considering the needs of external financing, capital needs theory proposes that companies in need of funds will disclose more information than what is required by regulations or laws [24].

As mentioned above, using the concept of agency theory, it is often suggested that there is a positive correlation between company characteristics (size, leverage, etc.) and the level of voluntary disclosure [25]. We will be exploring several characteristics and their association with integrated reporting. In addition, stakeholder and legitimacy theory are mentioned when looking for explanations to why companies disclose voluntary information, which is often in context with corporate social responsibility. Lastly, signaling and capital needs theory are cited when a company is in a particular situation and decides to disclose non-mandatory information proactively. We will expand the application of these theories to information disclosure in integrated reports.

To this day, it is still largely unclear why certain companies prepare better quality integrated reports than others. This research study is trying to fill this gap using an exploratory and empirical research approach.

\subsection{Literature Review and Development of Hypotheses}

Many of the previous studies on voluntary information disclosure have focused on various kinds of voluntary information disclosure such as sustainability reporting or environmental reporting. Some looked into determinants of voluntary disclosure in particular countries or regions [26-33]. Others examined the relationship between certain characteristics in connection with voluntary information disclosure [34-37]. For example, it was found that larger organizations will disclose more corporate social responsibility (CSR) information than smaller ones [25,28,38-40].

Several other studies specifically examined disclosure via integrated reports in certain countries, such as Japan, South Africa, or Indonesia [9,39,41,42]. Some other studies identified several explanatory factors that impact integrated reporting [42-45]. Another research approach has been to examine specific determinants that have an impact on a certain type of disclosure in integrated reporting such as forward-looking information [46]. Further, some studies on firm characteristics focused on the integrated reporting disclosure level of companies of the IIRC pilot program [16], and it was found that these reporters reached medium levels of disclosure [47]. Overall, an increase of disclosure level has 
been observed since the introduction of the integrated reporting requirement for listed companies in South Africa. Still, research on integrated reporting is still quite limited. This research study broadens the investigation into integrated reporting and its corporate characteristics by using a global sample of companies.

While South Africa has been a pioneer in the development of integrated reporting, some other countries have come to embrace the idea of the integrated reporting framework early on as well [45]. Examples are the United Kingdom (UK), Japan, and Australia. Early corporate adopters of integrated reporting include Novo Nordisk, Efficient Group, and Imperial Logistics. By now, large companies such as Marks and Spencer, Unilever, L'Oréal, Pfizer, and Fujitsu are preparing an annual integrated report. In addition, almost 300 listed Japanese companies have adopted integrated reporting [48].

North American companies have often been said to be lagging behind with regard to voluntary reporting, while the movement has flourished in places such as Europe, South Africa, and Asia [24,49]. This has been empirically shown in previous research studies on sustainability reporting [28,50]. Often times, it has been argued that companies are influenced by their customers and their sensitivity to CSR and CSR reporting [51]. Similarly, in a recent research study on integrated reporting, it was found that the majority of integrated reporters are from Europe [52]. In South Africa, perhaps also due to the requirement for IR at the JSE, it was found that companies are more likely to produce an integrated report than in other countries $[33,38,43]$. For South African organizations, since the introduction of integrated reporting, the disclosure of social and relationship, human, natural, and intellectual capital has increased significantly for listed companies [41]. Another statistical study revealed significant differences among integrated reports by geographic location [39]. Therefore, for our first hypothesis, it is proposed that for companies in different countries, the quality of integrated reports companies will differ.

H1. The quality of integrated reports of companies will be related to the location of the company.

Previous research studies $[25,33,34,40,53-55]$ concluded that the volume of voluntary disclosures is positively related to the size of the company. When selecting a proxy for company size, Dang et al. [55] recommended researchers to use total assets if the size refers to the total resources from which the company can generate profit. Generally, and in accordance with agency theory, it seems that large companies disclose more information voluntarily due to their higher sensitivity to political costs, giving them additional incentives for voluntary disclosures [24]. It was found that integrated reporting and company size correlate positively $[43,56,57]$. Therefore, for the purpose of our study, it is assumed that this also applies to integrated reporting for a global sample, and we posit the hypothesis that:

H2. The quality of integrated reports of companies will be positively related to company size.

Prior research has also noted that voluntary disclosures are influenced by industry membership. Industries with a sensitive environment have been known to provide more information on non-financial aspects [51]. In general, it was found that voluntary disclosures are more frequent and comprehensive in some industries than others $[25,35,50,51,57,58]$. With regard to integrated reporting it is assumed that this applies as well; therefore, it is hypothesized that:

H3. The quality of integrated reports of companies will be related to the industry in which the company operates.

Signaling theory suggests that more profitable companies will voluntarily publish information to distinguish themselves from less profitable organizations. Various research studies that examine the relationship between profitability and voluntary disclosure found that more profitable companies disclose better quality information $[25,52,58]$. For instance, it was found that profitability was positively and significantly associated with voluntary disclosure levels for Kenyan financial institutions [36]. The results of a study analyzing Egyptian companies suggest that there is a positive significant correlation between firm profitability and the overall corporate governance voluntary disclosure extent [30]. Also, it was concluded that the reports of less profitable companies are less precise and more optimistic [59]. Therefore, in the fourth hypothesis, it is assumed that: 
H4. The quality of integrated reports of companies will be positively related to the profitability of the company.

According to agency theory, corporate creditors will ask for more information with increasing debt as they try to decrease information asymmetry, and according to capital needs theory, companies in need of external funding will disclose information voluntarily. Previous studies indicated a positive correlation between voluntary sustainability disclosure and the debt level of corporations $[60,61]$. One study found this only to be true for economic information disclosure [25]. Consequently, our hypothesis will be the following:

H5. The quality of integrated reports of companies will be positively associated with the leverage of the company.

Some previous studies examined the relationship between earnings quality and voluntary disclosure. For example, Francis et al. (2008) [62] concluded that companies with good earnings quality display more expansive voluntary disclosure. In the context of integrated reporting, in a study on listed Indonesian mining companies, it was determined that there is a positive correlation between earnings quality and integrated reporting [42]. For our sixth hypothesis, it is posited that this will apply to our global sample of organizations, and it is suggested that:

\section{H6. The quality of integrated reports of companies will be positively related to corporate earnings quality.}

In the past, female leaders have been found to be less manipulative and more ethical and transparent in regard to information disclosure [62-66]. In particular, it was established that female directors positively impact financial reporting disclosure [67-69]. As previously indicated by Vermeir and Van Kenhove (2007) [70], female directors show a low propensity to commit fraud as well as a superior commitment to apply higher ethical standards in the decision-making process [71], which leads to increased transparency in sustainability disclosures [68,72,73]. Other evidence supports these findings that female directors are more focused on disclosing more balanced, concise, clear, comparable, and reliable information in sustainability reports [62]. The results of a study of Sri Lankan companies confirm that boards with more female directors disclose more information in their sustainability reports than boards with predominantly male directors [53]. A positive correlation was also found between sustainability disclosure and female directors for Australian companies [74]. In addition, a study based on a Canadian company sample concluded that the likelihood of voluntary climate change disclosure also increases with a higher female director ratio [75]. It is hypothesized that this will also apply to non-mandatory information disclosure in the form of the integrated reports as follows:

H7. The quality of integrated reports of companies will be positively associated with the ratio of female board members of the company.

Academic researchers have also started looking into the impact of executive gender and its effect on voluntary information disclosure and found that female executives and voluntary disclosure of forward-looking information have a significant and positive association [76]. Based on this, in our next hypothesis, it is assumed that the effects of female participation in the executive team are also transferable to voluntary integrated reporting as follows:

H8. The quality of integrated reports of companies will be positively associated with the ratio of females in the executive team of the company.

Non-executive directors are often listed as a tool to avoid agency conflicts and to ensure independence from management [77]. Prior research indicates that external or outside board members ensure that companies engage in voluntary disclosure $[30,41,62,78]$. Others found that board independence had a positive and significant impact on corporate disclosure [53,79]. Ong and Djajadikerta (2017) [74] concluded that there is a positive correlation between independent directors and sustainability disclosure for listed companies in Australia. Consequently, it is assumed that a larger ratio of external board members will lead to a higher level of voluntary disclosure including integrated reporting, as follows: 
H9. The quality of integrated reports of companies will be positively associated with the ratio of external board members of the company.

In 2011, the IIRC started the two-year IIRC Pilot Programme initiative with 40 global companies in which the journeys of the IIRC Pilot Programme businesses and investors were detailed as they work toward $<\mathrm{IR}>$ [16]. It was designed to help the IIRC with developing the IR framework [16]. A recent research study that analyzed disclosure levels of integrated reports published by IIRC's Pilot Programme members found a significant association of disclosure level for company reports that were published on the IIRC website [16]. In another initiative, for a number of years now, the IIRC has been adding integrated reports to their website to the so-called Integrated Reporting Examples Database developed with British consulting firm Black Sun that contains examples of emerging practice in integrated reporting [79]. The reports listed have been suggested by the IIRC, Black Sun, and other supporters of $<\mathrm{IR}>$, including academia [80]. For example, Lai et al. (2014) [44] found that adopters of $<\mathrm{IR}>$ have significantly higher disclosure ratings relative to non-adopters. Therefore, it is assumed that companies listed in the IIRC examples database will have a significantly higher disclosure level and quality than others as follows:

H10. The quality of integrated reports of companies will be positively associated with the integrated report of the company being published in the IIRC examples database.

In general, the credibility of reports can often be raised through assurance [81,82]. In fact, it is typically assumed that an audit report can be considered as a proxy for quality $[51,83]$. Many stakeholders believe that hiring an external assurance provider for a voluntary report increases the probability of mischaracterization of activities to be identified [84], and by adding an external auditor report, companies provide further assurance on their details [51]. Therefore, it is posited that:

H11. The quality of integrated reports will be positively associated with the integrated report has been externally audited.

It is noteworthy that the first integrated report was published in 2002 [57]. As companies have had very different pathways in becoming integrated reporters, the question arises if reporting experience will have an impact on reporting quality. For example, Novo Nordisk just published its $14^{\text {th }}$ integrated report. One would think that this gives the organization an advantage over new reporters. In fact, previous research linked the disclosure quality of sustainability reports to the reporting experience of companies [85]. Therefore, we assume that this also applies to integrated reporting, and our last hypotheses is as follows:

H12. The quality of integrated reports will be positively associated with the number of the previous integrated reports published.

\section{Research Approach}

\subsection{Sample Selection and Data Collection}

Our sample consisted of 110 global companies and organizations that published an integrated report for the fiscal year 2017: some as stand-alone reports, and some in addition to the annual financial report. To find these companies, an internet search was undertaken using a Google search with the search terms "Integrated report" with the operator "AND" and "2017".

\subsection{Dependent Variables}

The scores for the dependent variables for each of the six capitals and eventually the total average disclosure score were determined by using a qualitative coding process involving the qualitative software Nvivo. The process started with the collection of specific words or terms related to the respective capital. Prior to that, terms were accumulated by researching information sources related to 
each capital. These information sources included numerous web pages, books, magazines, articles, blogs, journals, etc., directly or indirectly related to integrated reporting and long-term value creation. Then, the terms were used as search words in Nvivo, which highlighted all occurrences in the integrated reports. After a careful analysis of the highlighted texts for their suitability in our context, these text passages were then copied into a spreadsheet to their respective capital category.

In doing so, we relied on the most common technique used to analyze economic, social, and environmental information, which is content analysis [86]. Content hereby refers to words, meanings, and any messages that can be communicated [87]. Generally, content is coded into various categories or concepts depending on selected criteria [88], and coding can be manual or computer-aided [89]. Content analysis has been widely used to analyze social and environmental disclosures in a variety of reports [5,90-92].

After having collected the information, the data had to be coded to identify the different levels of disclosure related to the six capitals, and ultimately the overall disclosure level of the individual integrated report. As mentioned previously, it was decided to assess disclosure for the individual six capitals, and then to add each score using the same weight for each capital to arrive at an evenly weighted total integrated report disclosure score. Many different ways to code qualitative information can be found in the qualitative research literature [93]. Self-constructed scores have successfully been used in a number of empirical studies, especially if there is no generally accepted metric available [94]. After carefully considering the specific nature of information, it was decided to use a six-score coding scale that was deemed detailed enough to differentiate between different levels of disclosure, but not to have too many levels to still be able to effortlessly assign the correct scores. According to the chosen scoring criteria (termed none, inadequate, weak, moderate, good, and exceptional), we assigned six numerical values: $0,1,2,3,4$, and 5 . As mentioned above, in determining each score, each capital included scores for various topics related to the capital (for a complete list of topics, see Table A1 in the Appendix). The different scoring levels considered not only whether the information is provided on a certain topic, but also in how much detail and if actual numbers and/or metrics (quantitative data) are provided. Based on the scoring, with the minimum score of 0 and a maximum of 5 for each capital making, the total disclosure score was a maximum of 30. Cronbach's alpha was calculated to test the internal consistency for the content analysis, and the score of 0.791 was deemed satisfactory, as many methodologists recommend a minimum coefficient between $0.65-0.8$.

\subsection{Independent Variables}

The demographic data for the independent variables were also extracted mainly from the integrated report itself. However, in case the information was not found in the report, then the financial report, the proxy, or the company websites had to be consulted. In more rare incidents, the company was contacted via email about the missing information on certain variables.

\subsection{Research Method}

We also included a control variable into the model to account for possible alternative explanations. The control variable "word number" was included in our regression model, which was similar to previous studies where the effects on the dependent variable were previously tested [51,95].

To empirically assess the influence of the above variables on the amount of disclosure by firms, the following ordinary least square (OLS) regression model is employed to examine the study hypotheses:

Total IR Disclosure Score

$$
\begin{aligned}
& =\alpha+\beta_{1} \text { Currency }+\beta_{2} \text { Size }+\beta_{2} \text { Industry }+\beta_{4} \text { Profitability } \\
& +\beta_{5} \text { Leverage }+\beta_{6} \text { Earnings quality }+\beta_{7} \text { Female executives } \\
& +\beta_{8} \text { Female board members } \\
& +\beta_{9} \text { Outside board members }+\beta_{10} \text { IRRC examples base } \\
& +\beta_{11} \text { External assurance }+\beta_{12} \text { Number of reports }+\varepsilon
\end{aligned}
$$


OLS is a standard linear regression methodology that has been used by several researchers analyzing the voluntary disclosures practices of organizations (e.g., [30,96-99]).

The next section will present descriptive and correlation results followed by the empirical regression results.

\section{Research Results}

\subsection{Descriptive Statistics Results}

Table 1 presents the descriptive analysis for the categorical (dichotomous and nominal) independent variables used in the regression model for the sample. The currency name and industry group represent a variable with different categories in which the sample companies report in and operate. As can be seen in Table 1,40\% of companies used the South African Rand as reporting currency, and 34\% used the Japanese Yen. Some other companies reported in British Pounds (8\%), the Euro (6\%) and the United States (US) Dollar (5\%). Additional companies used the Australian Dollar, New Zealand Dollar, Swiss Francs, Polish Zloty, Danish Krone, and Indian Rupee. The companies were active in various industry groups, most notably in industry group 4, which included several services (43\%), and industry group 3 (consumer goods and others), with 19\% (see also Figure A1 in the Appendix). Less than one-third of companies in the sample has been added to the IIRC examples database, and only $6 \%$ indicated that their integrated report was externally assured.

Table 2 presents the descriptive analysis for the continuous independent variables and the Total Disclosure Score used in the regression model for the sample. With regard to governance aspects, the female executive officer and the female board member variables are measured as the percentage of the overall executive and board member number, respectively. The Outside Board Member variable is measured as the percentage of external independent board members in relation to the overall board member number. It is a proxy for governance.

To include a size-related variable, the natural logarithm of total assets in US dollars was used. The variable leverage was calculated as total liabilities divided by total assets. As a profit-related measure, the financial ratio net profit/net income margin was calculated by determining the net income as a percentage of total revenues. For the calculation of earnings quality, cash flow from operations was divided by net income. As mentioned above, the total disclosure score is the sum of all six capital disclosure scores. Finally, we controlled for the number of words, which is measured as the natural logarithm of total words used in the integrated report.

As can be seen in Table 2, the sample included companies and organizations of all sizes with total assets ranging from $\$ 30$ million to $\$ 188$ billion with a mean of almost $\$ 20$ billion. The net profit margin ranged from -36 to $2660 \%$. Previously, between zero and 21 previous integrated reports were published by the individual sample organizations. The female executive ratio ranged from $0 \%$ to $71 \%$ while the female board member ratio was $0 \%$ to $67 \%$. The outside board member ratio was between $6-100 \%$. The lowest total disclosure score was 1.0 , and the highest score was 27 , with an average of 10.8. The shortest integrated report comprised 11,200 words, and the longest was almost 200,000 words long. The average was at an impressive 55,600 words. 
Table 1. Independent variables names, types, frequencies in number, and \%. IR: integrated reporting, IT: information technology, MGMT: management.

\begin{tabular}{|c|c|c|c|c|c|}
\hline Hypothesis & Name & Description & Type of Variable & Frequency & $\%$ \\
\hline \multirow[t]{12}{*}{$\mathrm{H} 1$} & Currency_name & $\begin{array}{l}\text { Currency used in } \\
\text { integrated report }\end{array}$ & Dummy: & & \\
\hline & & & $1=\mathrm{ZAR}$ & 44 & $40.0 \%$ \\
\hline & & & $2=\mathrm{JPY}$ & 37 & $33.6 \%$ \\
\hline & & & $3=\mathrm{GBP}$ & 9 & $8.2 \%$ \\
\hline & & & $4=\mathrm{EUR}$ & 7 & $6.4 \%$ \\
\hline & & & $5=\mathrm{USD}$ & 5 & $4.5 \%$ \\
\hline & & & $6=\mathrm{AUD}$ & 1 & $0.9 \%$ \\
\hline & & & $7=\mathrm{NZD}$ & 3 & $2.7 \%$ \\
\hline & & & $8=\mathrm{CHF}$ & 1 & $0.9 \%$ \\
\hline & & & $9=$ PLN & 1 & $0.9 \%$ \\
\hline & & & $10=\mathrm{DKK}$ & 1 & $0.9 \%$ \\
\hline & & & $11=\mathrm{INR}$ & 1 & $0.9 \%$ \\
\hline \multirow[t]{7}{*}{$\mathrm{H} 3$} & Industry groups & $\begin{array}{l}\text { Industry sector to which } \\
\text { the organization belongs }\end{array}$ & Dummy & & \\
\hline & & & $1=$ Oil and gas, energy, mining & 11 & $10.0 \%$ \\
\hline & & & $2=$ Pharma, transportation & 11 & $10.0 \%$ \\
\hline & & & $3=$ Consumer goods, cosmetics, parts and equipment, electronics & 21 & $19.1 \%$ \\
\hline & & & $\begin{array}{c}4=\text { Financial services, food, IT, media, professional services, } \\
\text { property MGMT, retail, telecommunication }\end{array}$ & 47 & $42.7 \%$ \\
\hline & & & $5=$ Conglomerate \& other & 9 & $8.2 \%$ \\
\hline & & & $6=$ Chemicals, construction, electric utility & 11 & $10.0 \%$ \\
\hline \multirow[t]{3}{*}{ H10 } & In IR examples database & In IIRC examples database & Dummy: & & \\
\hline & & & $0=$ no & 76 & $69.1 \%$ \\
\hline & & & $1=$ yes & 34 & $30.9 \%$ \\
\hline \multirow[t]{3}{*}{$\mathrm{H} 11$} & IR_ext_assured & $\begin{array}{l}\text { Integrated report } \\
\text { externally audited }\end{array}$ & Dummy: & & \\
\hline & & & $0=$ no & 104 & $94.5 \%$ \\
\hline & & & $1=$ yes & 6 & $5.5 \%$ \\
\hline$n=110$ & & & & & \\
\hline
\end{tabular}


Table 2. Descriptive statistics for continuous independent variables and disclosure score.

\begin{tabular}{|c|c|c|c|c|c|c|c|}
\hline Hypothesis & Variable Name & Variable Explanation & Variable Type & $\begin{array}{l}\text { Expected Sign and } \\
\text { Relationship }\end{array}$ & Minimum & Maximum & Mean \\
\hline $\mathrm{H} 2$ & Total assets in USD & $\begin{array}{c}\text { Total assets in USD in } 2017 \text { financial } \\
\text { report }\end{array}$ & $\begin{array}{l}\text { Independent } \\
\text { variable }\end{array}$ & $\begin{array}{l}\text { (+) Variable Total assets has a } \\
\text { significant positive } \\
\text { relationship with IR quality }\end{array}$ & $\$ 29,624,880$ & $\$ 187,902,320,700$ & $\$ 19,734,411,138$ \\
\hline $\mathrm{H} 4$ & Net profit margin & Net income/Revenues & $\begin{array}{l}\text { Independent } \\
\text { variable }\end{array}$ & $\begin{array}{l}\text { (+) Variable Net income has a } \\
\text { significant positive } \\
\text { relationship with IR quality }\end{array}$ & $-35.9 \%$ & $2660.0 \%$ & $33.623 \%$ \\
\hline H5 & Leverage & Total liabilities/Total assets & $\begin{array}{l}\text { Independent } \\
\text { variable }\end{array}$ & $\begin{array}{l}\text { (-) Variable Leverage has a } \\
\text { significant positive } \\
\text { relationship with IR quality }\end{array}$ & 0.0234 & 2.1997 & 0.547004 \\
\hline H6 & Earnings_quality & $\begin{array}{l}\text { Cash flow from operating } \\
\text { activities/Net income }\end{array}$ & $\begin{array}{l}\text { Independent } \\
\text { variable }\end{array}$ & $\begin{array}{l}\text { (+) Variable Earnings quality } \\
\text { has a significant positive } \\
\text { relationship with IR quality }\end{array}$ & -985.1 & 1573.3 & 167.421 \\
\hline H11 & $\begin{array}{l}\text { How many IR } \\
\text { published } \\
\text { previously }\end{array}$ & $\begin{array}{l}\text { Number of integrated reports } \\
\text { organization has published so far }\end{array}$ & $\begin{array}{l}\text { Independent } \\
\text { variable }\end{array}$ & $\begin{array}{l}(+) \text { Variable Female executive } \\
\text { has a significant positive } \\
\text { relationship with IR quality }\end{array}$ & 0 & 21 & 3.16 \\
\hline $\mathrm{H} 7$ & $\begin{array}{l}\text { Female executive } \\
\text { officers }\end{array}$ & $\begin{array}{l}\text { Ratio of female executive officers of } \\
\text { total executive officers }\end{array}$ & $\begin{array}{l}\text { Independent } \\
\text { variable }\end{array}$ & $\begin{array}{l}(+) \text { Variable Female executive } \\
\text { has a significant positive } \\
\text { relationship with IR quality }\end{array}$ & $0.0 \%$ & $71.4 \%$ & $14.439 \%$ \\
\hline $\mathrm{H} 8$ & $\begin{array}{l}\text { Female board } \\
\text { members }\end{array}$ & $\begin{array}{l}\text { Ratio of female board members of } \\
\text { total board members }\end{array}$ & $\begin{array}{l}\text { Independent } \\
\text { variable }\end{array}$ & $\begin{array}{l}\text { (+) Variable Female director } \\
\text { has a significant positive } \\
\text { relationship with IR quality }\end{array}$ & $0.0 \%$ & $66.7 \%$ & $20.528 \%$ \\
\hline \multirow[t]{3}{*}{ H9 } & $\begin{array}{l}\text { Outside board } \\
\text { members }\end{array}$ & $\begin{array}{l}\text { Ratio of external board members of } \\
\text { total board members }\end{array}$ & $\begin{array}{l}\text { Independent } \\
\text { variable }\end{array}$ & $\begin{array}{l}(+) \text { Variable Outside director } \\
\text { has a significant positive } \\
\text { relationship with IR quality }\end{array}$ & $5.6 \%$ & $100.0 \%$ & $56.921 \%$ \\
\hline & Word_numbers & $\begin{array}{l}\text { Number of total words in } \\
\text { integrated report }\end{array}$ & Control variable & $\begin{array}{l}(+) \text { Variable Word number } \\
\text { has a significant positive } \\
\text { relationship with IR quality }\end{array}$ & $11,201.0$ & $197,605.0$ & $55,585.5$ \\
\hline & Total score (max: 30$)$ & $\begin{array}{l}\text { Total quality score calculated by } \\
\text { adding natural capital, } \\
\text { manufactured capital, financial } \\
\text { capital, social \& relationship capital, } \\
\text { Intellectual capital \& human capital } \\
\text { score (maximum 30) }\end{array}$ & $\begin{array}{l}\text { Dependent } \\
\text { variable }\end{array}$ & & 1.0 & 27.0 & 10.764 \\
\hline
\end{tabular}




\subsection{Inferential Statistics Results}

\subsubsection{Univariate Analysis}

Since some of the independent variables were ratio variables and normality could not be assumed, the correlations between variables were calculated using Spearman's rho. Table 3 presents the univariate Spearman correlations.

The sample consists of 110 firm-year observations during the fiscal year 2017. From the data, it can be deduced that there are low and moderate correlations among variables. Several correlations are noteworthy. Firstly, the number of integrated reports published, and the net income margin, are positively associated with the total disclosure score at the $1 \%$ level. This suggests that companies with a higher disclosure score for their reports have more experience in integrated reporting. It also suggests that companies that have a higher disclosure score are more profitable. Secondly, the outside board member ratio is also positively associated with the total disclosure score at the $1 \%$ level. Thus, the univariate results suggest that organizations with a higher total disclosure score have more external members on their board of directors. Lastly, both the variables related to the female executive ratio, as well as the female board member ratio, are positively correlated with the total disclosure score at the $1 \%$ level. The same is true for the number of words used in the report. This means that companies with higher female participation produce better integrated reports. It can also be concluded that longer integrated reports are, on average, of better quality.

\subsubsection{Multivariate Analysis}

Turning to multivariate analysis, a multiple linear regression analysis was performed. Table 4 shows the results of this multiple linear regression analysis. As can be seen, the overall model is significant at the 0.000 level, with an adjusted R square of 50\%, meaning that the variables included explain $50 \%$ of the dependent variable Total Disclosure Score. The regression data was examined for the assumptions of linearity, normality of residuals, low multicollinearity, and homoscedasticity.

Since linear regression needs the relationship between the independent and dependent variables to be linear, we used scatterplots and checked for outliers and concluded that linearity is present. In addition, normality $\mathrm{P}$ plots were developed, and their analysis confirmed the normality of the residuals. After calculation of the variance inflation (VIF) values, it was found that all the independent variables have low VIF values (all lower than 5.1) with high tolerance levels, which confirms the absence of multicollinearity. Then, the analysis of scatterplots of residuals were used to rule out heteroscedasticity.

When examining our data in detail, we conclude that it is possible that one of our explanatory variables, female executive ratio, is endogenous. Not taking endogeneity into account could cause bias in our estimates [100]. In order to address this potential issue, we use a two-stage least squares instrumental variable (2SLS-IV) estimator. In the study context, an instrument is valid if it is correlated with variables, including female executive ratio (instrument relevance), and if it affects integrated reporting quality indirectly and solely through its association with the female executive ratio (instrument exogeneity). However, finding variables that can serve as credible instruments can be quite difficult [101].

Nevertheless, researchers interested in the study of the causal impact on reporting quality have to confront this potential endogeneity problem [102]. We identified four instruments that we believe are likely correlated to the female executive ratio, but not to the overall integrated reporting quality: Having a sustainability or CSR board committee, inclusion in the Morgan Stanley Capital International Index (MSCI), number of employees, and the corporate efficiency ratio operating cash flow ratio. 
Table 3. Spearman correlations.

\begin{tabular}{|c|c|c|c|c|c|c|c|c|c|c|c|c|}
\hline \multicolumn{13}{|c|}{ Correlations } \\
\hline & & & $\begin{array}{l}\text { How Many } \\
\text { IR Published } \\
\text { Previously }\end{array}$ & $\begin{array}{l}\text { Net } \\
\text { Income } \\
\text { Margin }\end{array}$ & Leverage_Percent & Earnings_Quality & $\begin{array}{c}\text { Female } \\
\text { Executive } \\
\text { Officers }\end{array}$ & $\begin{array}{c}\text { Female } \\
\text { Board } \\
\text { Members }\end{array}$ & $\begin{array}{l}\text { Outside } \\
\text { Board } \\
\text { Members }\end{array}$ & Ln_Assets & Ln_Words & $\begin{array}{l}\text { Total Disclosure } \\
\text { Score (Max: 30) }\end{array}$ \\
\hline \multirow{3}{*}{\multicolumn{2}{|c|}{$\begin{array}{l}\text { How many IR } \\
\text { published } \\
\text { previously }\end{array}$}} & $\begin{array}{l}\text { Correlation } \\
\text { Coefficient }\end{array}$ & 1.000 & -0.079 & -0.058 & -0.055 & 0.090 & $0.206^{*}$ & 0.116 & $-0.272 * *$ & $0.235 *$ & $0.251 * *$ \\
\hline & & Sig. (2-tailed) & & 0.411 & 0.549 & 0.567 & 0.352 & 0.031 & 0.229 & 0.004 & 0.013 & 0.008 \\
\hline & & $\mathrm{N}$ & 110 & 110 & 110 & 110 & 110 & 110 & 110 & 110 & 110 & 110 \\
\hline \multirow{18}{*}{$\begin{array}{l}\text { Spearman's } \\
\text { rho }\end{array}$} & \multirow{3}{*}{$\begin{array}{l}\text { Net income } \\
\text { margin }\end{array}$} & $\begin{array}{l}\text { Correlation } \\
\text { Coefficient }\end{array}$ & -0.079 & 1.000 & $-0.335^{* *}$ & -0.177 & $0.273^{* *}$ & 0.025 & 0.075 & 0.061 & 0.118 & $0.248 * *$ \\
\hline & & Sig. (2-tailed) & 0.411 & & 0.000 & 0.064 & 0.004 & 0.798 & 0.433 & 0.524 & 0.220 & 0.009 \\
\hline & & $\mathrm{N}$ & 110 & 110 & 110 & 110 & 110 & 110 & 110 & 110 & 110 & 110 \\
\hline & \multirow{3}{*}{ Leverage_percent } & $\begin{array}{l}\text { Correlation } \\
\text { Coefficient }\end{array}$ & -0.058 & $-0.335^{* *}$ & 1.000 & 0.149 & 0.044 & 0.144 & 0.011 & $0.340^{* *}$ & 0.147 & -0.002 \\
\hline & & Sig. (2-tailed) & 0.549 & 0.000 & & 0.119 & 0.646 & 0.132 & 0.905 & 0.000 & 0.125 & 0.984 \\
\hline & & $\mathrm{N}$ & 110 & 110 & 110 & 110 & 110 & 110 & 110 & 110 & 110 & 110 \\
\hline & \multirow{3}{*}{ Earnings_quality } & $\begin{array}{l}\text { Correlation } \\
\text { Coefficient }\end{array}$ & -0.055 & -0.177 & 0.149 & 1.000 & -0.133 & -0.004 & -0.154 & $0.405^{* *}$ & -0.042 & -0.071 \\
\hline & & Sig. (2-tailed) & 0.567 & 0.064 & 0.119 & & 0.165 & 0.966 & 0.108 & 0.000 & 0.660 & 0.463 \\
\hline & & $\mathrm{N}$ & 110 & 110 & 110 & 110 & 110 & 110 & 110 & 110 & 110 & 110 \\
\hline & \multirow{3}{*}{$\begin{array}{c}\text { Female executive } \\
\text { officers }\end{array}$} & $\begin{array}{l}\text { Correlation } \\
\text { Coefficient }\end{array}$ & 0.090 & $0.273^{* *}$ & 0.044 & -0.133 & 1.000 & $0.508^{* *}$ & $0.343^{* *}$ & 0.044 & 0.127 & $0.285^{* *}$ \\
\hline & & Sig. (2-tailed) & 0.352 & 0.004 & 0.646 & 0.165 & & 0.000 & 0.000 & 0.652 & 0.187 & 0.003 \\
\hline & & $\mathrm{N}$ & 110 & 110 & 110 & 110 & 110 & 110 & 110 & 110 & 110 & 110 \\
\hline & \multirow{3}{*}{$\begin{array}{l}\text { Female board } \\
\text { members }\end{array}$} & $\begin{array}{l}\text { Correlation } \\
\text { Coefficient }\end{array}$ & $0.206^{*}$ & 0.025 & 0.144 & -0.004 & $0.508 * *$ & 1.000 & $0.487^{* *}$ & -0.087 & 0.038 & $0.382 * *$ \\
\hline & & Sig. (2-tailed) & 0.031 & 0.798 & 0.132 & 0.966 & 0.000 & & 0.000 & 0.364 & 0.691 & 0.000 \\
\hline & & $\mathrm{N}$ & 110 & 110 & 110 & 110 & 110 & 110 & 110 & 110 & 110 & 110 \\
\hline & \multirow{3}{*}{$\begin{array}{l}\text { Outside board } \\
\text { members }\end{array}$} & $\begin{array}{l}\text { Correlation } \\
\text { Coefficient }\end{array}$ & 0.116 & 0.075 & 0.011 & -0.154 & 0.343 ** & $0.487^{* *}$ & 1.000 & -0.176 & 0.086 & $0.273 * *$ \\
\hline & & Sig. (2-tailed) & 0.229 & 0.433 & 0.905 & 0.108 & 0.000 & 0.000 & & 0.066 & 0.372 & 0.004 \\
\hline & & $\mathrm{N}$ & 110 & 110 & 110 & 110 & 110 & 110 & 110 & 110 & 110 & 110 \\
\hline
\end{tabular}


Table 3. Cont

\begin{tabular}{|c|c|c|c|c|c|c|c|c|c|c|c|c|}
\hline \multicolumn{13}{|c|}{ Correlations } \\
\hline & & & $\begin{array}{l}\text { How Many } \\
\text { IR Published } \\
\text { Previously }\end{array}$ & $\begin{array}{l}\text { Net } \\
\text { Income } \\
\text { Margin }\end{array}$ & Leverage_Percent & Earnings_Quality & $\begin{array}{l}\text { Female } \\
\text { Executive } \\
\text { Officers }\end{array}$ & $\begin{array}{l}\text { Female } \\
\text { Board } \\
\text { Members }\end{array}$ & $\begin{array}{l}\text { Outside } \\
\text { Board } \\
\text { Members }\end{array}$ & Ln_Assets & Ln_Words & $\begin{array}{l}\text { Total Disclosure } \\
\text { Score (Max: 30) }\end{array}$ \\
\hline \multirow{9}{*}{$\begin{array}{l}\text { Spearman's } \\
\text { rho }\end{array}$} & \multirow{3}{*}{ Ln_assets } & $\begin{array}{l}\text { Correlation } \\
\text { Coefficient }\end{array}$ & $-0.272^{* *}$ & 0.061 & $0.340 * *$ & $0.405^{* *}$ & 0.044 & -0.087 & -0.176 & 1.000 & 0.075 & 0.028 \\
\hline & & Sig. (2-tailed) & 0.004 & 0.524 & 0.000 & 0.000 & 0.652 & 0.364 & 0.066 & & 0.436 & 0.772 \\
\hline & & $\mathrm{N}$ & 110 & 110 & 110 & 110 & 110 & 110 & 110 & 110 & 110 & 110 \\
\hline & \multirow{3}{*}{ Ln_words } & $\begin{array}{l}\text { Correlation } \\
\text { Coefficient }\end{array}$ & $0.235^{*}$ & 0.118 & 0.147 & -0.042 & 0.127 & 0.038 & 0.086 & 0.075 & 1.000 & $0.410 * *$ \\
\hline & & Sig. (2-tailed) & 0.013 & 0.220 & 0.125 & 0.660 & 0.187 & 0.691 & 0.372 & 0.436 & & 0.000 \\
\hline & & $\mathrm{N}$ & 110 & 110 & 110 & 110 & 110 & 110 & 110 & 110 & 110 & 110 \\
\hline & \multirow{3}{*}{$\begin{array}{l}\text { Total disclosure } \\
\text { score (max: 30) }\end{array}$} & $\begin{array}{l}\text { Correlation } \\
\text { Coefficient }\end{array}$ & $0.251 * *$ & $0.248^{* *}$ & -0.002 & -0.071 & $0.285^{* *}$ & $0.382 * *$ & $0.273^{* *}$ & 0.028 & $0.410 * *$ & 1.000 \\
\hline & & Sig. (2-tailed) & 0.008 & 0.009 & 0.984 & 0.463 & 0.003 & 0.000 & 0.004 & 0.772 & 0.000 & \\
\hline & & $\mathrm{N}$ & 110 & 110 & 110 & 110 & 110 & 110 & 110 & 110 & 110 & 110 \\
\hline
\end{tabular}

*. Correlation is significant at the 0.05 level (2-tailed). ${ }^{* *}$. Correlation is significant at the 0.01 level (2-tailed). 
Table 4. Estimation results, confidence intervals, and $p$-values for the OSL regression.

\begin{tabular}{|c|c|c|c|c|}
\hline \multicolumn{5}{|c|}{ Estimation Method } \\
\hline \multicolumn{5}{|c|}{ OLS } \\
\hline Variables & Coefficients & $t$-Student & $p$-value & Sig. \\
\hline (Constant) & -15.66 & -1.43 & 0.158 & \\
\hline Net income margin & 0.00 & -2.16 & 0.034 & $* *$ \\
\hline Leverage & -4.24 & -2.35 & 0.021 & $* *$ \\
\hline Earnings_quality & 0.00 & -1.24 & 0.217 & \\
\hline $\begin{array}{l}\text { How many IR published } \\
\text { previously }\end{array}$ & -0.21 & -1.19 & 0.239 & \\
\hline Female executive officers & -0.11 & -2.82 & 0.006 & $* * *$ \\
\hline Female board members & 0.14 & 2.86 & 0.005 & $* * *$ \\
\hline Outside board members & -0.03 & -1.26 & 0.212 & \\
\hline InIRRCexamplesdatabase $=$ yes & 4.09 & 3.26 & 0.002 & $* * *$ \\
\hline Currency $=\mathrm{ZAR}$ & excluded & & & \\
\hline Currency = JPY & -7.89 & -3.94 & 0.000 & $* * *$ \\
\hline Currency = GBP & -3.89 & -1.99 & 0.050 & $* *$ \\
\hline Currency = EUR & -2.99 & -1.32 & 0.190 & \\
\hline Currency = USD & -5.83 & -2.44 & 0.017 & $* *$ \\
\hline Currency = AUD & -11.68 & -2.22 & 0.029 & $* *$ \\
\hline Currency = NZD & -4.21 & -1.42 & 0.160 & \\
\hline Currency = CHF & 11.06 & 2.29 & 0.024 & $* *$ \\
\hline Currency = PLN & -6.60 & -1.29 & 0.201 & \\
\hline Currency = DKK & -10.63 & -2.08 & 0.040 & $* *$ \\
\hline Currency = RUP & 8.65 & 1.69 & 0.094 & $* *$ \\
\hline IR_ext_assured = no & -5.03 & -2.40 & 0.019 & $* *$ \\
\hline Ln_assets & 0.77 & 2.43 & 0.017 & $* *$ \\
\hline Ln_words & 1.53 & 1.56 & 0.124 & \\
\hline Industry_group $=1.0$ & -2.92 & -1.61 & 0.111 & \\
\hline Industry_group $=2.0$ & 2.91 & 1.73 & 0.087 & * \\
\hline Industry_group $=3.0$ & -2.22 & -1.63 & 0.106 & \\
\hline Industry_group $=4.0$ & excluded & & & \\
\hline Industry_group $=5.0$ & -1.59 & -0.93 & 0.355 & \\
\hline Industry_group $=6.0$ & 1.68 & 1.01 & 0.315 & \\
\hline $\mathrm{R} 2$ & 0.615 & & & \\
\hline
\end{tabular}

Notes: R2: 0.615, adjusted r2: $0.495,{ }^{*} p=0.10,{ }^{* *} p=0.05,{ }^{* * *} p=0.01$; Number of observations: 110; Excluded Variables: InIRRCexamplesdatabase $=$ no, Currency $=$ ZAR, IR_ext_assured $=$ yes, Industry_group $=4.0$.

In order to test robustness of our results, estimations are employed by using the STATA 15's routines ivregress (with the post-estimation commands "estat overid" and "estat firsts") and ivreg2. The option robust allows controlling for heteroskedastic errors. All weak instrument regressions were performed with the STATA addon ivreg2 [103].

As indicated underneath Table 5 the Anderson LM statistic for under-identification is 27.489 when the variable female executive ratio is treated as endogenous. As the Anderson canonical correlations LM statistic test is rejected, it is indicated that the identifying restrictions are valid for drawing causal interferences. The Cragg-Donald Wald F-statistic for the excluded instruments is 8.50, which is higher than Stock-Yogo's weak ID test critical values (IV relative bias and IV size) as 5\%, 10\%, 20\%, and 30\% indicate the largest relative bias of the 2SLS estimator to the OLS. The critical values only exist if the model is overidentified by at least two restrictions, and the Sargan statistic confirms that there are no issues for our model. The null hypothesis of each Stock and Yogo (2005) test is that the set of chosen instruments is weak [104]. In our case, we can reject the null hypothesis of weak instruments. 
Table 5. Estimation results, confidence intervals, and $p$-values for the 2SLS regression.

\begin{tabular}{|c|c|c|c|c|}
\hline \multicolumn{5}{|c|}{ 2SLS } \\
\hline (Constant) & Coefficients & $z$ & $p$-value & Sig. \\
\hline Net income margin & -0.72 & -6.13 & 0.000 & $* * *$ \\
\hline Leverage & -4.66 & -1.82 & 0.068 & ** \\
\hline Earnings_quality & -0.18 & -0.95 & 0.341 & \\
\hline How many IR published previously & -0.26 & -1.96 & 0.049 & $* *$ \\
\hline Female executive officers & -22.02 & -5.02 & 0.000 & $* * *$ \\
\hline Female board members & 14.42 & 3.21 & 0.001 & $* * *$ \\
\hline Outside board members & -12.16 & -3.04 & 0.002 & $* * *$ \\
\hline InIRRCexamplesdatabase $=$ no & -4.23 & -2.65 & 0.008 & $* * *$ \\
\hline Currency $=$ ZAR & -11.33 & -3.17 & 0.002 & $* * *$ \\
\hline Currency = JPY & -28.98 & -7.26 & 0.000 & $* * *$ \\
\hline Currency = GBP & -9.43 & -2.07 & 0.038 & $* *$ \\
\hline Currency = EUR & -22.71 & -4.41 & 0.000 & $* * *$ \\
\hline Currency = USD & -14.77 & -2.90 & 0.004 & $* * *$ \\
\hline \multicolumn{5}{|l|}{ Currency $=$ AUD } \\
\hline Currency = NZD & -12.67 & -2.99 & 0.003 & $* * *$ \\
\hline Currency = CHF & \multicolumn{4}{|l|}{ excluded } \\
\hline Currency = PLN & \multicolumn{4}{|l|}{ excluded } \\
\hline Currency $=\mathrm{DKK}$ & \multicolumn{4}{|l|}{ excluded } \\
\hline Currency = RUP & \multicolumn{4}{|l|}{ excluded } \\
\hline IR_ext_assured = yes & \multicolumn{4}{|l|}{ excluded } \\
\hline Ln_assets & 1.15 & 3.41 & 0.001 & \multirow{2}{*}{$* * *$} \\
\hline Ln_words & -4.68 & -3.57 & 0.000 & \\
\hline Industry_group $=1.0$ & 1.74 & 0.75 & 0.452 & \\
\hline Industry_group $=2.0$ & 1.18 & 0.51 & 0.612 & \\
\hline Industry_group $=3.0$ & -5.13 & -1.85 & 0.065 & * \\
\hline Industry_group $=4.0$ & 1.64 & 1.09 & 0.278 & \\
\hline Industry_group $=5.0$ & -0.91 & -0.39 & 0.695 & \\
\hline Industry_group $=6.0$ & excluded & & & \\
\hline $\begin{array}{l}\text { Anderson canon corr. LM statistics for } \\
\text { underidentification test }\end{array}$ & $27.489(\mathrm{p}=0.000)$ & & & \\
\hline \multirow{4}{*}{$\begin{array}{l}\text { Cragg-Donald Wald F statistic for } \\
\text { weak instrument test }\end{array}$} & 8.5 & & & \\
\hline & $5 \%$ maximal IV relative bias: 16.85 & & & \\
\hline & $10 \%$ maximal IV relative bias: 10.27 & & & \\
\hline & $20 \%$ maximal IV relative bias: 6.71 & & & \\
\hline Stock-Yogo weak ID test & $30 \%$ maximal IV relative bias: 5.34 & & & \\
\hline critical values: & $10 \%$ maximal IV size: 24.58 & & & \\
\hline & 15\% maximal IV size: 13.96 & & & \\
\hline & $20 \%$ maximal IV size: 10.26 & & & \\
\hline & $25 \%$ maximal IV size: 8.31 & & & \\
\hline $\begin{array}{l}\text { Sargan statistic: overidentification test } \\
\text { of all instruments Chi-sq: } 3.631\end{array}$ & $\mathrm{p}$-value $=0.3041$ & & & \\
\hline
\end{tabular}

Notes: Number of observations: $110,{ }^{*} p=0.10,{ }^{* *} p=0.05,{ }^{* * *} p=0.01$; Excluded Variables: InIRRCexamplesdatabase $=$ yes, Currency $=$ AUD, Currency $=$ CHF, Currency $=$ PLN, Currency $=$ DKK, Currency $=$ RUP, IR_ext_assured $=$ no, Industry_group $=6.0$; Instrumented variable: Female executive officers.

Another approach developed by Mikusheva and Poi (2006) suggests inference in the linear regression model with one endogenous variable and potentially weak instruments by constructing confidence sets for the coefficient on the endogenous variable by inverting the Anderson-Rubin, Lagrange multiplier, and conditional likelihood ratio tests [105]. The resulting confidence sets have correct coverage probabilities, even when the instruments are weak.

Therefore, we re-estimate the model using Stata's condivreg command, which allows robust inference in the presence of potentially weak instruments. The results do not change much. Since these tests provide acceptable support for the validity of our instruments and to control for potential 
biases due to endogeneity, we will focus on the estimates obtained using the 2SLS approach, but it is important to mention that both the OLS and the 2SLS regression provide very similar results.

The findings of this study show that firm characteristics such as female board ratio, total assets, and being in the IR examples database have a positive and significant relationship with integrated report disclosure quality, while the female executive officer ratio, external board member ratio, profitability, leverage, report length, and reporting experience have a negative and significant relationship with total integrated reporting disclosure quality.

In more detail, the regression results show that the variables related to net income margin, leverage, and total assets have a significant association with the total disclosure score at the 0.05 significance level. However, the regression coefficient for net income and leverage is negative, while it is positive for total assets. This means that organizations of a larger size and/or with lower leverage are more likely to produce a high-quality integrated report. As for the variable leverage, it can be concluded that companies with higher leverage will have a lower overall disclosure score. Similarly, companies with a higher net income margin will show a lower score. Thus, Hypothesis 2 is accepted, and H4 and $\mathrm{H} 5$ are rejected. The variables related to female executive and board member ratio show a relationship at the 0.01 significance level. However, while the female board ratio has a positive relationship, the female executive officer ratio has a negative relationship with the total disclosure score. Therefore, Hypothesis 7 is rejected, and $\mathrm{H} 8$ is accepted.

For the variable In IR Examples database, the dummy variable 0 is omitted ( 0 stands for not in database); therefore, we compared our results to this variable, and concluded that companies that are listed in the database show a significantly higher total disclosure score (by four units) than the others. Therefore, we can accept Hypothesis 10. For the variable regarding how many IR were published previously and Outside board member ratio, the results show a significant negative association with the dependent variable. Therefore, we can reject hypotheses 9 and 12. With respect to currencies, we find no conclusive significant information based on the 2SLS model, as many of the currency variables were excluded. For industry groups, External assurance and Earnings quality, no significant results were found. Therefore, hypotheses 1, 3, 6, and 11 are not supported, and we cannot draw any conclusions.

With regard to the control variable, the study results also suggest a significant negative relationship between word number and integrated report quality.

In summary, the research results, which are summarized in Table 6, are consistent with previous research for the variables related to female board member ratio, company size, and IIRC example database. However, the results are inconsistent and insignificant for the variables related to industry group, currency, and earnings quality. Finally, the results are inconsistent (but significant) with prior research studies for the variables related to profitability, leverage, outside board members, report length, previous reporting experience, and female executive officer ratio.

In more detail, the findings consistent with prior literature indicate that larger companies disclose better quality voluntary integrated information. Therefore, our study results are aligned with many other previously mentioned studies on voluntary information disclosure. Our univariate and multivariate research analysis also documents the significant positive influence of female directors on greater integrated reporting quality. This supports the argument for female participation in supervisory boards. The evidence is consistent with several previous papers about accounting conservatism and forecasted errors $[33,106,107]$. 
Table 6. Results of hypotheses testing.

\begin{tabular}{|c|c|c|c|c|c|}
\hline Hypothesis & Variable Name & Variable Explanation & Variable Type & Expected Sign and Relationship & Empirical Result \\
\hline $\mathrm{H} 2$ & Total assets in USD & $\begin{array}{l}\text { Total assets in USD in } 2017 \\
\text { financial report }\end{array}$ & Independent variable & $\begin{array}{l}\text { (+) Variable Total assets has a significant positive } \\
\text { relationship with IR quality }\end{array}$ & accepted \\
\hline $\mathrm{H} 4$ & $\begin{array}{l}\text { Net income margin } \\
\text { (profitability) }\end{array}$ & Net income/Revenues & Independent variable & $\begin{array}{l}\text { (+) Variable Net income has a significant } \\
\text { positive relationship with IR quality }\end{array}$ & rejected \\
\hline H5 & Leverage & Total liabilities/Total assets & Independent variable & $\begin{array}{l}\text { (-) Variable Leverage has a significant negative } \\
\text { relationship with IR quality }\end{array}$ & rejected \\
\hline H6 & Earnings_quality & $\begin{array}{l}\text { Cash flow from operating } \\
\text { activities/Net income }\end{array}$ & Independent variable & $\begin{array}{l}(+) \text { Variable Earnings quality has a significant } \\
\text { positive relationship with IR quality }\end{array}$ & not significant \\
\hline $\mathrm{H} 7$ & Female executives officers & $\begin{array}{l}\text { Ratio of female executive officers of } \\
\text { total executive officers }\end{array}$ & Independent variable & $\begin{array}{c}\text { (+) Variable Female executive has a significant } \\
\text { positive relationship with IR quality }\end{array}$ & rejected \\
\hline $\mathrm{H} 8$ & Female board members & $\begin{array}{l}\text { Ratio of female board members of } \\
\text { total board members }\end{array}$ & Independent variable & $\begin{array}{l}(+) \text { Variable Female director has a significant } \\
\text { positive relationship with IR quality }\end{array}$ & accepted \\
\hline \multirow[t]{2}{*}{ H9 } & Outside board members & $\begin{array}{l}\text { Ratio of external board members of } \\
\text { total board members }\end{array}$ & Independent variable & $\begin{array}{l}\text { (+) Variable Outside director has a significant } \\
\text { positive relationship with IR quality }\end{array}$ & rejected \\
\hline & Word_numbers & $\begin{array}{l}\text { Number of total words in } \\
\text { integrated report }\end{array}$ & Control variable & $\begin{array}{l}(+) \text { Variable Word number has a significant } \\
\text { positive relationship with IR quality }\end{array}$ & rejected \\
\hline $\mathrm{H} 12$ & $\begin{array}{l}\text { How many IR published } \\
\text { previously }\end{array}$ & $\begin{array}{l}\text { Number of integrated reports } \\
\text { organization has published so far }\end{array}$ & Independent variable & $\begin{array}{c}\text { (+) Variable Female executive has a significant } \\
\text { positive relationship with IR quality }\end{array}$ & not significant \\
\hline Hypothesis & Name & Description & & Expected differences & \\
\hline $\mathrm{H} 1$ & Currency_name & Currency used in integrated report & Independent variable & $\begin{array}{l}\text { There are significant differences between } \\
\text { locations with regard to IR quality scores }\end{array}$ & not significant \\
\hline H3 & Industry groups & $\begin{array}{l}\text { Industry sector to which the } \\
\text { organization belongs }\end{array}$ & Independent variable & $\begin{array}{l}\text { There are significant differences between groups } \\
\text { with regard to IR quality scores }\end{array}$ & not significant \\
\hline $\mathrm{H} 10$ & $\begin{array}{l}\text { In IRRC examples } \\
\text { database }\end{array}$ & In IIRC examples database & Independent variable & $\begin{array}{l}\text { Companies in IR database have higher IR } \\
\text { quality scores }\end{array}$ & accepted \\
\hline H11 & IR_ext_assured & Integrated report externally audited & Independent variable & $\begin{array}{c}\text { Companies in IR database have higher IR } \\
\text { quality scores }\end{array}$ & not significant \\
\hline
\end{tabular}


However, the negative significant correlation between total integrated reporting quality score and female executive ratio paints a somewhat different picture. This contradicts the results of the correlation, which indicated a positive association. As indicated earlier, there are not many research studies that have investigated the relationship between female executive ratio and voluntary disclosure. A French study found that while female directorship reduces earnings management practices, women in chief executive officer (CEO) and chief financial officer (CFO) positions do not affect earnings management practices [108]. Analyzing data on a Finnish sample, one author found that with regard to accounting conservatism, female managers are said to be more conservative [109], and this could possibly be also applied to an integrated information disclosure scenario. In order to find out more and support the results of our study, further research is definitely recommended.

In addition, we found a significant negative correlation between external directors and disclosure quality in integrated reports. This is actually in accordance with the results from Frias-Aceituno (2012) [39] and Prado-Lorenzo and Garcia-Sanchez (2010) [73], which suggested a very limited influence of external directors on voluntary sustainability disclosure.

As leverage and its association with the quality of integrated reporting is concerned, our results do not confirm that companies with higher leverage publish higher quality reports. Rather, our results indicate a negative significant association with the dependent variable of integrated report quality. This means that companies with a higher financial leverage will not prepare better quality reports. As mentioned before, several studies found a positive effect of leverage on voluntary reporting quality, including Elfeky (2017), who found a negative relationship between firm leverage and voluntary disclosure for a sample of Egyptian public companies [30]. These results contradict the argument made through agency theory that leveraged firms are more likely to disclose more information in order to reduce increased agency costs [19]. It is also consistent with the result of an Eng and Mak study (2003) [98], but inconsistent with many other studies [110-112] which either found positive or no significant association. Uyar (2013) also found a negative association between the two variables, and argued that it can be explained by a company with a higher debt level not disclosing information to maintain its competitive market position [113].

Further, the results show that companies listed in the IIRC example database are more likely to produce a better quality report. This is not surprising, since the reports in this database have been recommended for their quality by knowledgeable parties.

As another example, in our univariate results, we found that both the company publishing experience of integrated reports and report length are significantly correlated with the total disclosure score. In the OLS regression analysis, these variables were not significant, but in the 2SLS regression, a significant negative association was calculated for experienced IR reporters and the length of reports. This is surprising and needs to be explored further. The negative association of reporting experience and reporting quality might be explained by the different legal requirements for integrated reports. Companies listed at the JSE might have been preparing integrated reports for many years, and they have no other choice other than to prepare and file them with the stock exchange. Other companies that choose to prepare an integrated report might perceive it as a tool to improve on their long-term thinking and value creation; therefore, a high-quality report could be the result.

When it comes to report length, the results from a sample of IR early adopters show that in the presence of a firm's weak financial performance, the IR tends to be significantly longer, less readable, and more optimistic [59]. The authors of this study found also that companies with worse social performance use impression management techniques to provide reports that are less concise and less informative regarding their sustainability performance. Therefore, it might make sense that lengthier reports are of lower quality.

Lastly, the variable profitability proved to have a significant impact on the total disclosure score; however, it is not positive as predicted, but rather negative. This result contradicts many findings in earlier research literature as well as the univariate results of our study. However, some studies found no significant relationship between disclosure and profitability, and relate this finding with 
the prevailing attitude of the companies toward the stock market [114]. One study conducted on annual reports of Polish companies for total CSR and environmental and social disclosure did not find any association between disclosure level and profitability [115]. This is also consistent with a study conducted for companies listed at the JSE [33].

To summarize, we recommend further research in order to determine if there is any significance to the variables location or industry.

\section{Conclusions and Recommendation}

The purpose of our study was to examine certain company characteristics and their influence on integrated reporting quality. A few years ago, Anderson (2014) [116] concluded that there are still low sustainability report quality scores, even after years of reporting experience. While sustainability reporting is becoming a matter that is increasingly important for large public companies with global operations, integrated reporting is often considered to be still in its infancy [49]. This raises concerns about integrated reporting quality. Du Toit (2017) [117] stated that integrated reports are difficult to understand, especially for inexperienced readers. Haji and Anifowose (2016) [118] concluded that the current IR practice is still largely ceremonial in nature, in line with many similar statements, with the objective of acquiring or maintaining organizational legitimacy. Then, why are some companies capable of producing high-quality reports? According to Burke and Clark (2016) [2], collecting high-quality data for an integrated report is a time-consuming process, and if organizations put the effort in, they are sending a valuable signal to their stakeholders.

Chersan (2015) [119] found that internationally, there is an increase in the number of companies that publish an integrated report; however, the majority of these reports are deficient in regard to the long-term value creation process. Moreover, McNally et al. (2017) [120] cautioned that companies still don't take non-financial reporting as seriously as financial reporting. As long as there is no mandatory regulation, progress probably will be slow. To speed the process up and before implementing rigorous regulation, further research is needed in the areas of why and how companies are implementing integrating thinking and how and what kind of reports emerge as a result of this process. In line with this, Rinaldi et al. (2018) [121] urged many new avenues of research with regard to integrated reporting.

In line with this, many possible channels that have not been explored in the integrated reporting quality context is executive compensation linked to strategies that include and implement long-term value thinking, as well as reporting similar to [122-124]. Other topics such as executive incentives including equity grants similar to [125], CEO tournaments [126,127], or mutual CEO monitoring [128] within a longer-term perspective need further exploration.

Another possible channel through which integrated report quality could be determined is the research area of corporate governance. This includes the research of optimal internal governance structures in support of long-term value creation similar to $[129,130]$.

Our study contributes to the literature in several ways. To the best of our knowledge, we provide the first empirical evidence on the correlation between IR disclosure and company characteristics for a global sample. The results of our paper have several implications. First off, we expand the literature on integrated reporting and voluntary reporting overall regarding the impact of leadership and board diversity. Our evidence argues that there should be greater female board participation in order to raise the quality of integrated reporting. To our knowledge, there is no previous research that examines female executive officer and female board member ratios in the context of the quality of integrated reports. Even though some countries have introduced new requirements or guidelines to increase female representation (e.g., Norway, Belgium, Netherlands, Spain, Italy, France, Germany, and the United Kingdom (UK)), women are still largely underrepresented on company boards [131]. As for implementing mandatory female ratios, the Organization for Economic Co-operation and Development (OECD) published recommendations in 2017 regarding gender targets to increase the number of female directors [132]. In the United States, the state of California plans to require publicly listed companies 
to have at least one woman on their boards of directors by the end of 2019 [133]. The European Union also tries to push for a $40 \%$ quota for women on company boards [134].

Mandatory regulation in the area of non-financial reporting seems to be working in South Africa. Therefore, standard setters and regulators in other countries might want to think about this option rather sooner than later. Whether they should require specific standards such as the IIRC or leave this choice up to the companies needs further investigation. For example, Simnett and Huggins (2016) [45] suggested that to gain international acceptance, the market-based benefits of adopting any framework must be demonstrated.

There are also limitations of this study that can represent new areas for future research. The first limitation is that the empirical evidence in our sample is restricted to 15 countries and 110 organizations, and only reports for the fiscal year 2017 were included in the analysis. These limitations need to be addressed in future research by increasing the research sample and adding observations for different years. In addition, our research can only offer approximately $50 \%$ of an explanation for integrated reporting quality. Thus, it is important to look for other determinants of integrated reporting quality. Another important limitation that we encountered related to finding instrumental variables for our endogenous variable, the female executive ratio. It is hoped that future research can find better suited exogenous variables unrelated to the dependent variable integrated reporting quality.

Finally, our findings will hopefully be of significant interest to financial analysts, investors, and other stakeholders trying to determine the effects of company characteristics on voluntary disclosure in general and integrated reporting in particular. In addition, they are relevant to standard setters and local and international regulators, who could use them to increase standards for information transparency and comparability.

Author Contributions: Conceptualization, P.D. and S.C.; Methodology, P.D.; Software, S.C.; Validation, P.D. and S.C.; Formal Analysis, P.D. and S.C.; Resources, S.C.; Data Curation, P.D.; Writing-Original P.D; Writing-Review \& Editing, S.C.

Funding: This research received no external funding.

Conflicts of Interest: The authors declare no conflict of interest. 


\section{Appendix A}

Table A1. List of topics for each capital.

\begin{tabular}{|c|c|c|c|c|c|c|}
\hline & Financial Capital & $\begin{array}{c}\text { Social \& Relationship } \\
\text { Capital }\end{array}$ & Intellectual Capital & Natural Capital & Human Capital & Manufactured Capital \\
\hline 1 & $\begin{array}{l}\text { Financial capital in } \\
\text { business model }\end{array}$ & $\begin{array}{l}\text { SR capital in } \\
\text { business model }\end{array}$ & $\begin{array}{l}\text { Business model Inputs, } \\
\text { activities, outputs, } \\
\text { outcomes }\end{array}$ & $\begin{array}{l}\text { Business model Inputs, } \\
\text { activities, outputs, } \\
\text { outcomes }\end{array}$ & $\begin{array}{l}\text { Business model Inputs, } \\
\text { activities, outputs, } \\
\text { outcomes }\end{array}$ & $\begin{array}{l}\text { Business model Inputs, } \\
\text { activities, outputs, } \\
\text { outcomes }\end{array}$ \\
\hline 2 & $\begin{array}{l}\text { value added statement } \\
\text { (Financial capital) }\end{array}$ & $\begin{array}{l}\text { value added statement } \\
\text { (SR capital) }\end{array}$ & Value added statement & Value added statement & Value added statement & Value added statement \\
\hline 3 & $\begin{array}{c}\text { core values / value creation } \\
\text { distribution }\end{array}$ & $\begin{array}{l}\text { core values / value } \\
\text { creation distribution }\end{array}$ & $\begin{array}{l}\text { core values / value } \\
\text { creation distribution }\end{array}$ & $\begin{array}{l}\text { core values / value } \\
\text { creation distribution }\end{array}$ & $\begin{array}{l}\text { core values / value } \\
\text { creation distribution }\end{array}$ & $\begin{array}{l}\text { core values / value } \\
\text { creation distribution }\end{array}$ \\
\hline 4 & KPIs & KPIs & KPIs & KPIs & KPIs & KPIs \\
\hline 5 & $\begin{array}{l}\text { STH wealth creation } \\
\text { generated value creation* }\end{array}$ & Capital input & IT infrastructure & renewable / green energy & $\begin{array}{l}\text { employee development \& } \\
\text { training }\end{array}$ & ports \\
\hline 6 & distributed value & Capital output & Brand awareness & Energy usage and savings & employee, employees & roads \\
\hline 7 & corporate value creation ${ }^{*}$ & Capital outcome & Brand power & energy & employee satisfaction & bridges \\
\hline 8 & SH value creation* & relationships(s) & Brand value & electricity expenses & employee engagement & buildings \\
\hline 9 & LT sustainable value* & Employee relationships & reputation & $\begin{array}{c}\mathrm{CO} 2 \text { direct emissions / air } \\
\text { quality }\end{array}$ & board diversity & facilities \\
\hline 10 & asset turnover ratio & $\begin{array}{l}\text { Good corporate } \\
\text { citizenship }\end{array}$ & (new) patents & carbon footprint & management diversity & factories \\
\hline 11 & inventory turnover & SDG impact & filed patents & $\begin{array}{l}\text { Volatile organic } \\
\text { compounds, VOC } \\
\text { emissions }\end{array}$ & employee diversity & plants \\
\hline 12 & Purchase of PPE & Achievements & number of patents & Nox emissions & diversity & leased \\
\hline 13 & total assets & Communities / society & trademarks & SOx (tonnes) & $\begin{array}{l}\text { Disabling injury } \\
\text { frequency rate (“DIFR") }\end{array}$ & owned \\
\hline 14 & $\begin{array}{l}\text { turnover (gross or net) sales, } \\
\text { revenues }\end{array}$ & Social license to operate & copyrights & Particulate matter & $\begin{array}{l}\text { Lost time injury } \\
\text { frequency rate (LTIFR) }\end{array}$ & equipment \\
\hline 15 & $\begin{array}{l}\text { CAGR, revenue growth, sales } \\
\text { growth rate }\end{array}$ & Stakeholder relationships & licenses & climate change & injuries & machines \\
\hline 16 & $\begin{array}{c}\text { order book value quality } \\
\text { or growth }\end{array}$ & Customer satisfaction & royalties & climate in general & accidents & tools \\
\hline 17 & comprehensive income & $\begin{array}{l}\text { relationship with } \\
\text { customers }\end{array}$ & R\&D (expenses) & $\begin{array}{c}\text { diesel/fuel } \\
\text { consumption/transportation }\end{array}$ & fatalities, deaths & infrastructure \\
\hline 18 & $\begin{array}{l}\text { gross contribution, gross } \\
\text { profit, gross margin }\end{array}$ & stakeholder engagement & $\begin{array}{l}\text { Organizational systems, } \\
\text { procedures \& protocols }\end{array}$ & water consumption & safety & investment \\
\hline 19 & $\begin{array}{l}\text { IFRS gross profit, profit } \\
\text { before tax }\end{array}$ & Digital engagement & IT software systems & water expenses & retention, turnover & capital expenditures \\
\hline
\end{tabular}


Table A1. Cont.

\begin{tabular}{|c|c|c|c|c|c|c|}
\hline & Financial Capital & $\begin{array}{l}\text { Social \& Relationship } \\
\text { Capital }\end{array}$ & Intellectual Capital & Natural Capital & Human Capital & Manufactured Capital \\
\hline 20 & $\begin{array}{l}\text { operating margin, operating } \\
\text { income, operating profit, } \\
\text { contributions }\end{array}$ & relationship to media & (new) technology & water savings & benefits & capital projects \\
\hline 21 & $\begin{array}{l}\text { profit attributable to owners } \\
\text { of company }\end{array}$ & social media & (new) technology systems & waste water & $\begin{array}{l}\text { employee health \& } \\
\text { well-being }\end{array}$ & technology \\
\hline 22 & net income, Profit margin & Shareholder & $\begin{array}{l}\text { (new) technology } \\
\text { processes }\end{array}$ & recycled water usage & $\begin{array}{l}\text { compensation, minimal } \\
\text { wage }\end{array}$ & capital expenses \\
\hline 23 & $\begin{array}{l}\text { HEPS, headline earnings, } \\
\text { HEPS growth }\end{array}$ & Financial institutions & New products & paper usage & $\begin{array}{l}\text { employee remuneration / } \\
\text { incentives }\end{array}$ & material goods \\
\hline 24 & $\begin{array}{l}\text { underlying profit, } \\
\text { before/after tax, net income, } \\
\text { profit }\end{array}$ & investment community & $\begin{array}{l}\text { New products } \\
\text { development }\end{array}$ & $\begin{array}{l}\text { Hazardous pollutants, } \\
\text { chemical pollutants } \\
\text { (PRTR) }\end{array}$ & volunteering & material resources \\
\hline 25 & EBIT, underlying EBITDA & Analysts & $\begin{array}{c}\text { Expenditures on } \\
\text { organizational } \\
\text { change/process } \\
\text { development }\end{array}$ & $\begin{array}{l}\text { Responsibility for } \\
\text { environmental harm, } \\
\text { environmental training }\end{array}$ & work flexibility & \\
\hline 26 & $\begin{array}{l}\text { Operating } \mathrm{CF} \text {, Cash } \\
\text { generated from operations }\end{array}$ & NGOs & $\begin{array}{c}\text { Expenditures on } \\
\text { organizational process } \\
\text { development }\end{array}$ & waste/ packaging & $\begin{array}{l}\text { incidents, harassment, } \\
\text { discrimination }\end{array}$ & \\
\hline 27 & $\begin{array}{l}\text { production costs, operating } \\
\text { expenses, COGS, cost of sales }\end{array}$ & not for profit & $\begin{array}{l}\text { Expenditures on software, } \\
\text { development for internal } \\
\text { systems }\end{array}$ & incidents & $\begin{array}{l}\text { maternity leave, sick } \\
\text { leave, absenteeism }\end{array}$ & \\
\hline 28 & $\begin{array}{l}\text { total costs, total expenditures, } \\
\text { total expenses }\end{array}$ & job creation & $\begin{array}{l}\text { Expenditures on } \\
\text { development for internal } \\
\text { systems }\end{array}$ & spill(s) / & severance & \\
\hline 29 & cash operating profit & sponsorship & innovation & environ. accidents & unions & \\
\hline 30 & $\begin{array}{l}\text { cost per unit, operating cost } \\
\text { per unit }\end{array}$ & partnerships & awards & recycling & employee profile & \\
\hline 31 & $\begin{array}{c}\text { ROA, ROE, ROIC, } \\
\text { ROFE/ROCE }\end{array}$ & government & recognition & ground/soil use & $\begin{array}{l}\text { qualifications, skills, } \\
\text { knowledge }\end{array}$ & \\
\hline 32 & WACC & local authorities & & $\begin{array}{l}\text { green / eco investments } \\
\text { compliance with }\end{array}$ & recognition, awards & \\
\hline 33 & accounting return & regulatory bodies & & $\begin{array}{l}\text { environmental laws or } \\
\text { further }\end{array}$ & & \\
\hline 34 & annual production & legal compliance & & ISO certification & & \\
\hline 35 & $\begin{array}{l}\text { tax rate, tax contribution, } \\
\text { income tax }\end{array}$ & tax authorities & & carbon accreditation & & \\
\hline
\end{tabular}


Table A1. Cont.

\begin{tabular}{|c|c|c|c|c|c|c|}
\hline & Financial Capital & $\begin{array}{l}\text { Social \& Relationship } \\
\text { Capital }\end{array}$ & Intellectual Capital & Natural Capital & Human Capital & Manufactured Capital \\
\hline 36 & Liquidity & $\begin{array}{l}\text { relationship to industry } \\
\text { associations/NGOs }\end{array}$ & & $\begin{array}{l}\text { provide CDP score* / } \\
\text { information }\end{array}$ & & \\
\hline 37 & $\begin{array}{l}\text { Funding (equity \& dent), } \\
\text { Funds available }\end{array}$ & $\begin{array}{c}\text { Major contractors, } \\
\text { suppliers (vendors) }\end{array}$ & & accreditation & & \\
\hline 38 & $\begin{array}{l}\text { net debt, debt minus cash } \\
\text { on hand }\end{array}$ & donations & & awards / certification & & \\
\hline 39 & $\begin{array}{l}\text { Interest charge/expenses, } \\
\text { Costs of funding }\end{array}$ & philanthropy & & animal treatment & & \\
\hline 40 & Financing cost cover (times) & employee volunteering & & waste in general & & \\
\hline 41 & interest bearing debt & unions & & transportation waste & & \\
\hline 42 & loan to value ratio & academia collaborations & & SDGs references & & \\
\hline 43 & access to funding & research collaborations & & & & \\
\hline 44 & credit rating (strength) & collaborations & & & & \\
\hline 45 & $\begin{array}{c}\text { DER leverage ratio, debt to } \\
\text { equity ratio }\end{array}$ & community & & & & \\
\hline 46 & $\begin{array}{c}\text { SE/assets, Shareholders } \\
\text { equity ratio }\end{array}$ & & & & & \\
\hline 47 & gearing ratio & & & & & \\
\hline 48 & Current ratio & & & & & \\
\hline 49 & Acid test ratio & & & & & \\
\hline 50 & working capital & & & & & \\
\hline 51 & $\begin{array}{l}\text { operating assets, NAV, net } \\
\text { asset value, net assets }\end{array}$ & & & & & \\
\hline 52 & $\begin{array}{l}\text { NAV per share, net asset } \\
\text { value per share }\end{array}$ & & & & & \\
\hline 53 & EPS Earnings per share & & & & & \\
\hline 54 & EPS growth rate & & & & & \\
\hline 55 & $\mathrm{P} / \mathrm{E}$ ratio & & & & & \\
\hline 56 & (cash) Dividends per share & & & & & \\
\hline 57 & share return, $\mathrm{SH}$ return & & & & & \\
\hline 58 & $\begin{array}{c}\text { free cash flow, Cash flow } \\
\text { per share }\end{array}$ & & & & & \\
\hline 59 & Cash (flow) conversion & & & & & \\
\hline 60 & cash minus liab, net cash & & & & & \\
\hline 61 & Payout ratio, Dividend paid & & & & & \\
\hline 62 & $\begin{array}{c}\text { corporate value market } \\
\text { capitalization }\end{array}$ & & & & & \\
\hline
\end{tabular}


Table A1. Cont.

\begin{tabular}{|c|c|c|c|c|c|c|}
\hline & Financial Capital & $\begin{array}{c}\text { Social \& Relationship } \\
\text { Capital }\end{array}$ & Intellectual Capital & Natural Capital & Human Capital & Manufactured Capital \\
\hline 63 & Market price, Share price & & & & & \\
\hline 64 & $\begin{array}{c}\text { cash distribution to } \\
\text { shareholders }\end{array}$ & & & & & \\
\hline 65 & brand value & & & & & \\
\hline 66 & total expenditures, total costs & & & & & \\
\hline 67 & market share & & & & & \\
\hline 68 & $\begin{array}{l}\text { Investment capital } \\
\text { expenditures }\end{array}$ & & & & & \\
\hline 69 & capex & & & & & \\
\hline 70 & R\&D expenditures, R\&D & & & & & \\
\hline 71 & payroll expenses & & & & & \\
\hline 72 & training expenses & & & & & \\
\hline 73 & profit trading expenses & & & & & \\
\hline 74 & CSR spent, CSR expenses & & & & & \\
\hline
\end{tabular}




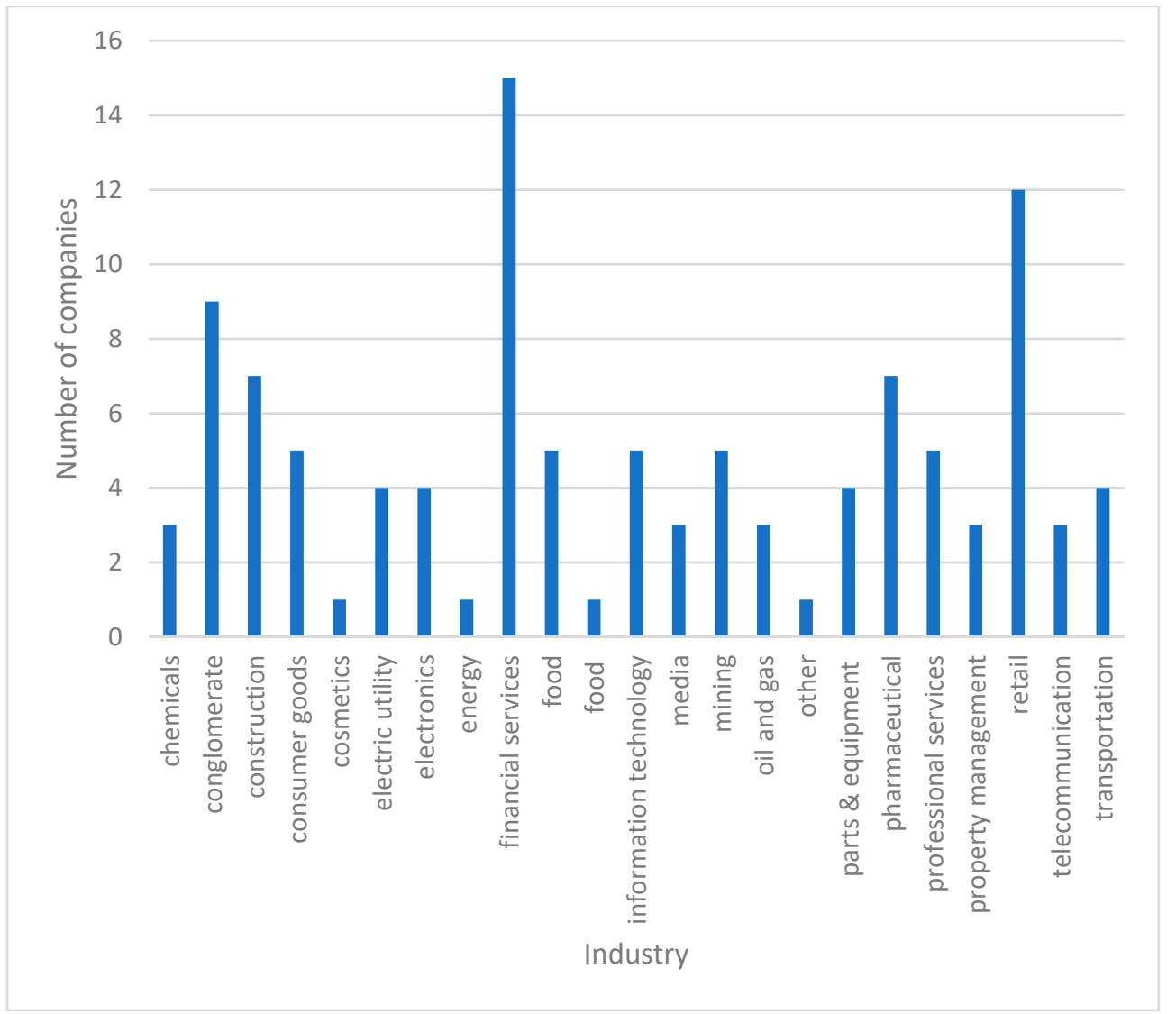

Figure A1. Sample organizations and number of organizations in specific industries.

\section{References}

1. Stewart, L.S. Growing demand for ESG information and standards: understanding corporate opportunities as well as risks. J. Appl. Corp. Financ. 2015, 27, 58-63. [CrossRef]

2. Burke, J.J.; Clark, C.E. The business case for integrated reporting: insights from leading practitioners, regulators, and academics. Bus. Horiz. 2016, 59, 273-283. [CrossRef]

3. Villiers, C.D.; Rinaldi, L.; Unerman, J. Integrated reporting: insights, gaps and an agenda for future research. Account. Audit. Account. J. 2014, 27, 1042-1067. [CrossRef]

4. Villiers, C.D.; Hsiao, P.K.; Maroun, W. Developing a conceptual model of influences around integrated reporting, new insights and directions for future research. Medit. Account. Res. 2017, 25, 450-460. [CrossRef]

5. Dilling, P.F.; Harris, P. Reporting on long-term value creation by Canadian companies: A longitudinal assessment. J. Clean. Prod. 2018, 191, 350-360. [CrossRef]

6. Villiers, C.D.; Maroun, W. The future of sustainability accounting and integrated reporting. Sustain. Account. Integr. Rep. 2017, 163, 163-170. [CrossRef]

7. Formation of the International Integrated Reporting Committee (IIRC). Formation of the International Integrated Reporting Committee (IIRC), IIRC, 2 Aug. 2010. Available online: www.integratedreporting.org/ news/formation-of-the-international-integrated-reporting-committee-iirc/ (accessed on 3 July 2019).

8. John, D.; Bernardi, C.; Guthrie, J.; La Torre, M. Barriers to implementing the international integrated reporting framework. Medit. Account. Res. 2017, 25, 461-480. [CrossRef]

9. Survey of Integrated Reports in Japan 2017. KPMG, Mar. 2018. Available online: www.home.kpmg/jp/en/ho me/insights/2017/06/integrated-reporting-20170614.html (accessed on 3 July 2019).

10. Institute of directors in Southern Africa. King Report on Governance for South Africa. 2009. Available online: https://cdn.ymaws.com/www.iodsa.co.za/resource/resmgr/king_iii/King_Report_on_Gove rnance_fo.pdf (accessed on 4 July 2019). 
11. International Framework. Integrated Reporting, IIRC. 2013. Available online: www.integratedreporting.org/ resource/international-ir-framework (accessed on 2 July 2019).

12. Strong, P.T. (Ed.) Sustainability reporting and the journey towards integrated reporting in Australia. In Proceedings of the Accounting and Finance Association of Australia and New Zealand (AFAANZ) Conference, Auckland, New Zealand, 6-8 July 2014.

13. Eccles, R.G.; Krzus, M.P. One Report: Integrated Reporting for a Sustainable Strategy; John Wiley \& Sons: Hoboken, NJ, USA, 2015.

14. Adams, C.A. The international integrated reporting council: A call to action. Crit. Perspect. Account. 2015, 27, 23-28. [CrossRef]

15. Eccles, R.G.; Krzus, M.P.; Ribot, S. Models of best practice in integrated reporting 2015. J. Appl. Corp. Financ. 2015, 27, 103-115. [CrossRef]

16. IIRC Pilot Programme Yearbook 2013: Business and Investors Explore the Sustainability Perspective. Integrated Reporting, IIRC. 2011. Available online: www.integratedreporting.org/resource/iirc-pilotprogramme-yearbook-2013-business-and-investors-explore-the-sustainability-perspective (accessed on 3 July 2019).

17. Adams, S.; Simnett, R. Integrated reporting: an opportunity for Australia's not-for-profit sector. Aust. Account. Rev. 2011, 21, 292-301. [CrossRef]

18. Hampton, R. Brace Yourself: More Regulatory Changes. CaseWare Africa. 2012. Available online: www.casewareafrica.co.za/interesting-reads/articles/brace-yourself-more-regulatory-changes/ (accessed on 3 July 2019).

19. Alves, H.; Rodrigues, A.M.; Canadas, N.; Rodrigues, A.M.; Canadas, N. Factors influencing the different categories of voluntary disclosure in annual reports: An Analysis for Iberian Peninsula listed companies. Tékhne 2012, 10, 15-26. [CrossRef]

20. Jensen, M.C.; Meckling, W.H. Theory of the firm: Managerial behavior, agency costs and ownership structure. J. Financ. Econ. 1976, 3, 305-360. [CrossRef]

21. Hill, C.W.; Jones, T.M. Stakeholder-agency theory. J. Manag. Stud. 1992, 29, 131-154. [CrossRef]

22. Baiman, S.; Verrecchia, R.E. The relation among capital markets, financial disclosure, production efficiency, and insider trading. J. Account. Res. 1996, 34, 1. [CrossRef]

23. Huang, C.L.; Kung, F.H. Drivers of environmental disclosure and stakeholder expectation: Evidence from Taiwan. J. Bus. Eth. 2010, 96, 435-451. [CrossRef]

24. Meek, G.K.; Roberts, C.B.; Gray, S.J. Factors Influencing voluntary annual report disclosures by, U.S., U.K. and continental European multinational corporations. J. Int. Bus. Stud. 1995, 26, 555-572. [CrossRef]

25. Gallego-Álvarez, I.; Quina-Custodio, I.A. Disclosure of corporate social responsibility information and explanatory factors. Online Inf. Rev. 2016, 40, 218-238. [CrossRef]

26. Hossain, M.; Reaz, M. The determinants and characteristics of voluntary disclosure by Indian banking companies. Corp. Soc. Responsib. Environ. Manag. 2007, 14, 274-288. [CrossRef]

27. Gamerschlag, R.; Möller, K.; Verbeeten, F. Determinants of voluntary CSR disclosure: Empirical evidence from Germany. Rev. Manag. Sci. 2010, 5, 233-262. [CrossRef]

28. Hackston, D.; Milne, M.J. Some determinants of social and environmental disclosures in New Zealand companies. Account. Audit. Account. J. 1996, 9, 77-108. [CrossRef]

29. Welbeck, E.E.; Owusu, G.M.Y.; Bekoe, R.A.; Kusi, J.A. Determinants of environmental disclosures of listed firms in Ghana. Int. J. Corp. Soc. Responsib. 2017, 2, 11. [CrossRef]

30. Elfeky, M. The impact of corporate governance on voluntary disclosure in emerging markets: The case of Egypt. Aust. J. Basic Appl. Sci. 2017, 11, 25-41.

31. Kansal, M.; Joshi, M.; Batra, G.S. Determinants of corporate social responsibility disclosures: Evidence from India. Adv. Account. 2014, 30, 217-229. [CrossRef]

32. Veronica Siregar, S.; Bachtiar, Y. Corporate social reporting: Empirical evidence from Indonesia stock exchange. Int. J. Islamic Middle East. Financ. Manag. 2010, 3, 241-252. [CrossRef]

33. Buitendag, N.; Fortuin, G.S.; De Laan, A. Firm characteristics and excellence in integrated reporting. S. Afr. J. Econ. Manag. Sci. 2017, 20,1-8. [CrossRef]

34. Botosan, C.A.; Plumlee, M. Disclosure level and expected cost of equity capital: An examination of analysts' rankings of corporate disclosure. SSRN Electron. J. 2000, 53. Available online: http://citeseerx.ist.psu.edu/vi ewdoc/download?doi=10.1.1.924.9988\&rep=rep1\&type=pdf (accessed on 4 July 2019). [CrossRef] 
35. Guidry, R.P.; Patten, D.M. Voluntary disclosure theory and financial control variables: An assessment of recent environmental disclosure research. Account. Forum 2012, 36, 81-90. [CrossRef]

36. Aikaeli, J.; Rashid, Z. Relationship between profitability and voluntary disclosure: A case of banks in Kenya. SSRN Electron. J. 2015, 25. Available online: https://papers.ssrn.com/sol3/papers.cfm?abstract_id=2706027 (accessed on 4 July 2019). [CrossRef]

37. Francis, J.; Nanda, D.; Olsson, P. Voluntary disclosure, earnings quality, and cost of capital. J. Account. Res. 2008, 46, 53-99. [CrossRef]

38. Clayton, A.F.; Rogerson, J.M.; Rampedi, I. Integrated reporting vs. sustainability reporting for corporate responsibility in South Africa. Bull. Geogr. Soc. Econ. Ser. 2015, 29, 7-17. [CrossRef]

39. Frias-Aceituno, J.V.; Rodríguez-Ariza, L.; Garcia-Sánchez, I.M. Explanatory factors of integrated sustainability and financial reporting. Bus. Strateg. Environ. 2012, 23, 56-72. [CrossRef]

40. Mathews, M.R. Twenty-five years of social and environmental accounting research. Account. Audit. Account. J. 1997, 10, 481-531. [CrossRef]

41. Setia, N.; Abhayawansa, S.; Joshi, M.; Huynh, A.V. Integrated reporting in South Africa: Some initial evidence. Sustain. Account. Manag. Policy J. 2015, 6, 397-424. [CrossRef]

42. Shanti; Tjahjadi, B.; Narsa, I.M. The Effect of Integrating Reporting on Earnings Quality: A Study of Family Firms in Indonesia. J. Fin. Bank. Review 2018, 3, 34-40. Available online: https://ssrn.com/abstract=3273901 (accessed on 4 July 2019).

43. Vaz, N.; Fernandez-Feijoo, B.; Ruiz, S. Integrated reporting: An international overview. Bus. Eth. A Eur. Rev. 2016, 25, 577-591. [CrossRef]

44. Lai, A.; Melloni, G.; Stacchezzini, R. Corporate sustainable development: Is 'integrated reporting' a legitimation strategy? Bus. Strateg. Environ. 2014, 25, 165-177. [CrossRef]

45. Simnett, R.; Huggins, A.L. Integrated reporting and assurance: Where Can research add value? Sustain. Account. Manag. Policy J. 2015, 6, 29-53. [CrossRef]

46. Kılıç, M.; Kuzey, C. Determinants of forward-looking disclosures in integrated reporting. Manag. Audit. J. 2018, 33, 115-144. [CrossRef]

47. García-Sánchez, I.-M.; Noguera-Gámez, L.; García-Sánchez, I.; Noguera-Gámez, L. Integrated Reporting and Stakeholder Engagement: The Effect on Information Asymmetry. Corp. Soc. Responsib. Environ. Manag. 2017, 24, 395-413. [CrossRef]

48. Ryohei, Y.; Michels-Kim, N. Integrating Nonfinancials to Create Value. Strategic Finance. 1 January 2018. Available online: www.sfmagazine.com/post-entry/january-2018-integrating-nonfinancials-to-create-va lue/?utm_content=buffer2e28a\&utm_medium=social\&utm_source=twitter.com\&utm_campaign=buffer (accessed on 4 July 2019).

49. Miller, K.C.; Fink, L.; Proctor, T.Y. Current trends and future expectations in external assurance for integrated corporate sustainability reporting. J. Legal Eth. Regul. Issues 2017, 20, 1-17.

50. Kolk, A. Trajectories of sustainability reporting by MNCs. J. World Bus. 2010, 45, 367-374. [CrossRef]

51. Rivera-Arrubla, Y.A.; Zorio-Grima, A.; García-Benau, M.A. Integrated reports: Disclosure level and explanatory factors. Soc. Responsib. J. 2017, 13, 155-176. [CrossRef]

52. Lopes, A.I.; Coelho, A.M. Engaged in integrated reporting? Evidence across multiple organizations. Eur. Bus. Rev. 2018, 30, 398-426. [CrossRef]

53. Rathnayaka Mudiyanselage, N.C.S. Board involvement in corporate sustainability reporting: Evidence from Sri Lanka. Corp. Gov. Int. J. Bus. Soc. 2018, 18, 1042-1056. [CrossRef]

54. Lan, Y.; Wang, L.; Zhang, X. Determinants and features of voluntary disclosure in the Chinese stock market. China J. Account. Res. 2013, 6, 265-285. [CrossRef]

55. Dang, C.; Li, Z.F.; Yang, C. Measuring firm size in empirical corporate finance. J. Bank. Financ. 2018, 86, 159-176. [CrossRef]

56. Frias-Aceituno, J.V.; Rodriguez-Ariza, L.; Garcia-Sanchez, I.M. The role of the board in the dissemination of integrated corporate social reporting. Corp. Soc. Responsib. Environ. Manag. 2012, 20, 219-233. [CrossRef]

57. Sierra-García, L.; Zorio-Grima, A.; García-Benau, M.A. Stakeholder engagement, corporate social responsibility and integrated reporting: An exploratory study. Corp. Soc. Responsib. Environ. Manag. 2013, 22, 286-304. [CrossRef]

58. Gianfelici, C.; Casadei, A.; Cembali, F. The relevance of nationality and industry for stakeholder salience: An investigation through integrated reports. J. Bus. Eth. 2016, 150, 541-558. [CrossRef] 
59. Melloni, G.; Caglio, A.; Perego, P. Saying more with less? Disclosure conciseness, completeness and balance in integrated reports. J. Account. Public Policy 2017, 36, 220-238. [CrossRef]

60. Xiao, J.Z.; Yang, H.; Chow, C.W. The determinants and characteristics of voluntary internet-based disclosures by listed Chinese companies. J. Account. Public Policy 2004, 23, 191-225. [CrossRef]

61. Clarkson, P.M.; Li, Y.; Richardson, G.D.; Vasvari, F.P. Revisiting the relation between environmental performance and environmental disclosure: An empirical analysis. Account. Organiz. Soc. 2008, 33, $303-327$. [CrossRef]

62. García-Sánchez, I.-M.; Martínez-Ferrero, J. Chief executive officer ability, corporate social responsibility, and financial performance: The moderating role of the environment. Bus. Strateg. Environ. 2018. Available online: https://onlinelibrary.wiley.com/doi/10.1002/bse.2263 (accessed on 5 July 2019). [CrossRef]

63. Barua, A.; Davidson, L.F.; Rama, D.V.; Thiruvadi, S. CFO gender and accruals quality. Account. Horiz. 2010, 24, 25-39. [CrossRef]

64. Gul, F.A.; Leung, S. Board leadership, outside directors' expertise and voluntary corporate disclosures. J. Account. Public Policy 2004, 23, 351-379. [CrossRef]

65. Hemingway, C.A.; Maclagan, P.W. Managers' personal values as drivers of corporate social responsibility. J. Bus. Eth. 2004, 50, 33-44. [CrossRef]

66. Ho, S.S.; Li, A.Y.; Tam, K.; Zhang, F. CEO gender, ethical leadership, and accounting conservatism. J. Bus. Eth. 2014, 127, 351-370. [CrossRef]

67. García-Sánchez, I.M.; Suárez-Fernández, O.; Martínez-Ferrero, J. Female directors and impression management in sustainability reporting. Int. Bus. Rev. 2018, 28, 359-374. [CrossRef]

68. Gul, F.A.; Srinidhi, B.; Ng, A.C. Does board gender diversity improve the informativeness of stock prices? J. Account. Econ. 2011, 51, 314-338. [CrossRef]

69. Gul, F.A.; Hutchinson, M.; Lai, K.M. Gender-diverse boards and properties of analyst earnings forecasts. Account. Horiz. 2013, 27, 511-538. [CrossRef]

70. Vermeir, I.; Van Kenhove, P. Gender differences in double standards. J. Bus. Eth. 2007, 81, 281-295. [CrossRef]

71. Thorne, L.; Mahoney, L.S.; Manetti, G. Motivations for issuing standalone CSR reports: A survey of Canadian firms. Account. Audit. Account. J. 2014, 27, 686-714. [CrossRef]

72. Barako, D.G.; Hancock, P.; Izan, H.Y. Factors influencing voluntary corporate disclosure by Kenyan companies. Corp. Gov. Int. Rev. 2006, 14, 107-125. [CrossRef]

73. Prado-Lorenzo, J.M.; Garcia-Sanchez, I.M. The role of the board of directors in disseminating relevant information on greenhouse gases. J. Bus. Eth. 2010, 97, 391-424. [CrossRef]

74. Ong, T.; Djajadikerta, H.G. Corporate governance and sustainability reporting in the Australian resources industry: An empirical analysis. Soc. Responsib. J. 2018. Available online: https://www.emerald.com/insight/ content/doi/10.1108/SRJ-06-2018-0135/full/html (accessed on 4 July 2019). [CrossRef]

75. Ben-Amar, W.; Chang, M.; McIlkenny, P. Board gender diversity and corporate response to sustainability initiatives: Evidence from the carbon disclosure project. J. Bus. Eth. 2015, 142, 369-383. [CrossRef]

76. Aribi, Z.A.; Alqatamin, R.M.; Arun, T. Gender diversity on boards and forward-looking information disclosure: evidence from Jordan. J. Account. Emerg. Econ. 2018, 8, 205-222. [CrossRef]

77. Fama, E.F.; Jensen, M.C. Separation of ownership and control. J. Law Econ. 1983, 26, 301-325. [CrossRef]

78. García-Sánchez,I.-M.; Cuadrado-Ballesteros, B.; Sepulveda, C. Does media pressure moderate CSR disclosures by external directors? Manag. Decis. 2014, 52, 1014-1045. [CrossRef]

79. “The IIRC launches Integrated Reporting Examples Database in conjunction with Black Sun". Integrated Reporting, IIRC. 2012. Available online: http://integratedreporting.org/news/the-iirc-launches-integrated-re porting-examples-database-in-conjunction-with-black-sun/ (accessed on 4 July 2019).

80. Muttakin, M.B.; Khan, A.; Subramaniam, N. Firm characteristics, board diversity and corporate social responsibility. Pac. Account. Rev. 2015, 27, 353-372. [CrossRef]

81. Simnett, R.; Vanstraelen, A.; Chua, W.F. Assurance on sustainability reports: An international comparison. Account. Rev. 2009, 84, 937-967. [CrossRef]

82. Al-Shaer, H.; Zaman, M. Credibility of sustainability reports: The contribution of audit committees. Bus. Strat. Environ. 2018, 27, 973-986. [CrossRef]

83. Carcello, J.V.; Hermanson, D.R.; Ye, Z. Corporate governance research in accounting and auditing: insights, practice implications, and future research directions. Audit. J. Pract. Theor. 2011, 30, 1-31. [CrossRef] 
84. Bagnoli, M.; Watts, S.G. Voluntary assurance of voluntary CSR disclosure. J. Econ. Manag. Strat. 2016, 26, 205-230. [CrossRef]

85. Truant, E.; Corazza, L.; Scagnelli, S.D. Sustainability and risk disclosure: An exploratory study on sustainability reports. Sustainibility 2017, 9, 636. [CrossRef]

86. Krippendorff, K. Content Analysis: An Introduction to Its Methodology, 2nd ed.; (9780761915447); Sage Publications, Inc.: Thousand Oaks, CA, USA, 2003.

87. Neuman, W.L.; Robson, K. Basics of Social Research: Qualitative and Quantitative Approaches; Pearson Canada Inc.: North York, ON, Canada, 2018.

88. Weber, R.F. Basic Content Analysis; Sage Publications, Inc.: Thousand Oaks, CA, USA, 2008.

89. Aureli, S. A comparison of content analysis usage and text mining in CSR corporate disclosure. Int. J. Digit. Account. Res. 2017, 17, 1-32. [CrossRef]

90. Milne, M.J.; Adler, R.W. Exploring the reliability of social and environmental disclosures content analysis. Account. Audit. Account. J. 1999, 12, 237-256. [CrossRef]

91. Guthrie, J.; Abeysekera, I. Content analysis of social, environmental reporting: what is new? J. Hum. Resour. Costing Account. 2006, 10, 114-126. [CrossRef]

92. Beck, C.; Dumay, J.; Frost, G. In pursuit of a 'single source of truth': From threatened legitimacy to integrated reporting. J. Bus. Eth. 2015, 141, 191-205. [CrossRef]

93. Saldaña, J. The Coding Manual for Qualitative Researchers; Sage Publications, Inc.: Thousand Oaks, CA, USA, 2016.

94. Palepu, K.G.; Healy, P. Business Analysis E Valuation: Using Financial Statements: Text. E Cases; South-Wester College Publishing: Nashville, TN, USA, 2004.

95. Martínez-Ferrero, J.; García-Sánchez, I.-M. Sustainability assurance and assurance providers: Corporate governance determinants in stakeholder-oriented countries. J. Manag. Organ. 2017, 23, 647-670. [CrossRef]

96. Boesso, G.; Kumar, K. Drivers of corporate voluntary disclosure. Account. Audit. Account. J. 2007, 20, $269-296$. [CrossRef]

97. Bozzolan, S.; Favotto, F.; Ricceri, F. Italian annual intellectual capital disclosure. J. Intellect. Cap. 2003, 4, 543-558. [CrossRef]

98. Eng, L.L.; Mak, Y. Corporate governance and voluntary disclosure. J. Account. Public Policy 2003, 22, 325-345. [CrossRef]

99. Marston, C.L.; Shrives, P.J. The use of disclosure indices in accounting research: A review article. Br. Account. Rev. 1991, 23, 195-210. [CrossRef]

100. Li, F. Endogeneity in CEO power: A survey and experiment. Invest. Anal. J. 2016, 45, 1-14. [CrossRef]

101. Bushway, S.; Johnson, B.D.; Slocum, L.A. Is the magic still there? the use of the heckman two-step correction for selection bias in criminology. J. Quant. Criminol. 2007, 23, 151-178. [CrossRef]

102. Skogan, W.; Frydl, K. Fairness and Effectiveness in Policing: The Evidence; The National Academies Press: Washington, DC, USA, 2003; Available online: www.nap.edu/catalog/10419/fairness-and-effectiveness-in-p olicing-the-evidence (accessed on 5 July 2019).

103. Baum, C.F.; Schaffer, M.E.; Stillman, S. Enhanced routines for instrumental variables/generalized method of moments estimation and testing. Stata J. Promot. Commun. Stat. Stata 2007, 7, 465-506. [CrossRef]

104. Stock, J.; Motohiro, Y. Testing for Weak Instruments in Linear IV Regression; National Bureau of Economic Research: Cambridge, MA, USA, 2002. [CrossRef]

105. Mikusheva, A.; Poi, B.P. Tests and confidence sets with correct size when instruments are potentially weak. Stata J. Promot. Commun. Stat. Stata 2006, 6, 335-347. [CrossRef]

106. Abbott, L.J.; Parker, S.; Presley, T.J. Female board presence and the likelihood of financial restatement. Account. Horiz. 2012, 26, 607-629. [CrossRef]

107. Srinidhi, B.; Gul, F.A.; Tsui, J. Female directors and earnings quality. Contemp. Account. Res. 2011, 28, 1610-1644. [CrossRef]

108. Lakhal, F.; Aguir, A.; Malek, A. Do women on boards and in top management reduce earnings management? Evidence in France. J. Appl. Bus. Res. (JABR) 2015, 31, 1107. [CrossRef]

109. Piiroinen, A. "The Effect of Gender on Accounting Conservatism in Finnish Listed Firms"; Hanken School of Economics, Helsinki, Department of Accounting and Commercial Law: Helsinki, Finland, 2019. 
110. AlSaeed, K. The association between firm-specific characteristics and disclosure. Manag. Audit. J. 2006, 21, 476-496. [CrossRef]

111. Huafang, X.; Jianguo, Y. Ownership structure, board composition and corporate voluntary disclosure. Manag. Audit. J. 2007, 22, 604-619. [CrossRef]

112. Chau, G.; Gray, S.J. Family ownership, board independence and voluntary disclosure: Evidence from Hong Kong. J. Int. Account. Audit. Tax. 2010, 19, 93-109. [CrossRef]

113. Uyar, A.; Kiliç, M.; Bayyurt, N. Association between firm characteristics and corporate voluntary disclosure: Evidence from Turkish listed companies. Intang. Cap. 2013, 9, 1080-1112. [CrossRef]

114. Arsov, S.; Bucevska, V. Determinants of transparency and disclosure-Evidence from post-transition economies. Econ. Res. 2017, 30, 745-760. [CrossRef]

115. Dyduch, J.; Krasodomska, J. Determinants of corporate social responsibility disclosure: An empirical study of polish listed companies. Sustainability 2017, 9, 1934. [CrossRef]

116. Anderson, L. What's the Story: An Exploration of North America's Pipeline Industry's Sustainability Reporting Practice; Royal Roads University: Victoria, BC, Canada, 2014.

117. Du Toit, E. The readability of integrated reports. Medit. Account. Res. 2017, 25, 629-653. [CrossRef]

118. Haji, A.A.; Anifowose, M. The trend of integrated reporting practice in South Africa: ceremonial or substantive? Sustain. Account. Manag. Policy J. 2016, 7, 190-224. [CrossRef]

119. Chersan, I.C. Study on practices and tendencies in integrated reporting. Audit. Financ. 2015, 9, 91-101.

120. McNally, M.-A.; Cerbone, D.; Maroun, W. Exploring the challenges of preparing an integrated report. Medit. Account. Res. 2017, 25, 481-504. [CrossRef]

121. Rinaldi, L.; Unerman, J.; De Villiers, C. Evaluating the integrated reporting journey: insights, gaps and agendas for future research. Account. Audit. Account. J. 2018, 31, 1294-1318. [CrossRef]

122. Hong, B.; Li, Z.F.; Minor, D. Corporate governance and executive compensation for corporate social responsibility. SSRN Electron. J. 2015, 71. Available online: https://papers.ssrn.com/sol3/papers.cfm?abstract _id $=2553963$ (accessed on 4 July 2019). [CrossRef]

123. Ikram, A.; Li, Z.F.; Minor, D. CSR-contingent executive compensation contracts. SSRN Electronic J. 2017. Available online: https://papers.ssrn.com/sol3/papers.cfm?abstract_id=3019985 (accessed on 4 July 2019). [CrossRef]

124. Li, Z.F.; Thibodeau, C. CSR-contingent executive compensation incentive and earnings management. Sustainability 2019, 11, 3421. [CrossRef]

125. Core, J.; Guay, W. The use of equity grants to manage optimal equity incentive levels. J. Account. Econ. 1999, 28, 151-184. [CrossRef]

126. Coles, J.L.; Wang, Y.A.; Li, Z.F. Industry tournament incentives. SSRN Electron. J. $2012,61$. Available online: https://www.semanticscholar.org/paper/Industry-Tournament-Incentives-Coles-Li/9a 643353af760b6610fb5948e922206971de6577 (accessed on 5 July 2019). [CrossRef]

127. Burns, N.; Minnick, K.; Starks, L.T. CEO tournaments: A cross-country analysis of causes, cultural influences and consequences. SSRN Electron. J. 2013. Available online: https://fisher.osu.edu/sites/default/files/ceo_t ournaments_a_cross-country_analysis_of_causes_cultural_influences_and_consequences.pdf (accessed on 4 July 2019). [CrossRef]

128. Li, Z.F. Mutual monitoring and corporate governance. J. Bank. Financ. 2014, 45, 255-269. [CrossRef]

129. Byun, H.S.; Park, K.S.; Hye, L.J. Corporate governance, product market competition, and payout policy. Seoul J. Bus. 2014, 20,1-34. [CrossRef]

130. Giroud, X.; Mueller, H.M. Corporate governance, product market competition, and equity prices. J. Financ. 2011, 66, 563-600. [CrossRef]

131. Cook, A.; Glass, C. Women and top leadership positions: Towards an institutional analysis. Gender Work Organ. 2013, 21, 91-103. [CrossRef]

132. OECD. The Pursuit of Gender Equality: An Uphill Battle; OECD Publishing: Paris, France, 2017. [CrossRef] 
133. Kumar, D.K. California State Law Mandates Female Board Directors by 2019. Reuters, Thomson Reuters, 1 Oct. 2018. Available online: www.reuters.com/article/us-california-board-women/california-state-law-man dates-female-board-directors-by-2019-idUSKCN1MB172 (accessed on 2 July 2019).

134. Boffey, D. EU to Push for $40 \%$ Quota for Women on Company Boards. The Guardian, Guardian News and Media, 20 Nov. 2017. Available online: www.theguardian.com/world/2017/nov/20/eu-to-push-for-40-quotafor-women-on-company-boards (accessed on 4 July 2019).

(c) (

(C) 2019 by the authors. Licensee MDPI, Basel, Switzerland. This article is an open access article distributed under the terms and conditions of the Creative Commons Attribution (CC BY) license (http://creativecommons.org/licenses/by/4.0/). 